\title{
ÍNDIOS DO BRASIL NA REPÚBLICA DOS PAÍSES BAIXOS: AS REPRESENTAÇÕES DE ANTÔNIO PARAUPABA PARA OS ESTADOS GERAIS EM 1654 E $1656^{*}$
}

Lodewijk Hulsman

U.V.A. Amsterdã

\section{Resumo}

O artigo publica uma tradução moderna do texto completo das representações de Antônio Paraupaba para o governo holandês em 1654 e 1656, acompanhada de uma introdução, anotações e comentário. A aliança potiguar-neerlandesa e a participação dos primeiros na política da Holanda é o tema central do estudo.

\section{Palavras-Chave}

Paraupaba • Fontes Indígenas • Brasil Holandês

\section{Abstract}

This article publishes the complete text of the Remonstrances of Antonio Paraupaba to the Dutch Government in 1654 and 1656 in a modernized Portuguese translation, with an introduction, annotation and commentary. The alliance between the Potiguar and the Dutch and the active participation of the former in Dutch politics is a central theme.

\section{Keywords}

Paraupaba • Indigenous Sources • Dutch Brazil

\footnotetext{
*Este artigo é baseado no artigo do mesmo autor, "Brazilian Indians in the Dutch Republic", Itinerario, Leiden, Vol 29/1, 2005.
} 


\section{Introdução}

A conquista de Olinda em 1630 por forças da Companhia das Índias Ocidentais (WIC) da República dos Países Baixos deu início àquilo que ficou conhecido como o Brasil Holandês. O empreendimento floresceu depois da nomeação do Conde Johann Moritz von Nassau-Siegen em 1636 como Governador Geral pelo conselho dirigente da WIC, os Heeren XIX (Senhores XIX). Recife tornou-se o centro administrativo de uma área que se estendia de Alagoas ao Maranhão. A insurreição de uma parte grande da população portuguesa em 1645, um ano depois da partida de Nassau, transformou Recife numa fortaleza assediada que se rendeu com todas as outras posses da WIC no Brasil no dia 26 de janeiro de 1654.

$\mathrm{O}$ folheto publicado por H. Hondius em 1657, com duas exposições do índio Antônio Paraupaba, é notável no sentido em que mostra uma relação continuada com o Brasil depois da rendição em 1654. Paraupaba se apresenta como representante dos índios brasilianos, leal para com a República neerlandesa e a religião reformada. O folheto também é notável na medida em que ilustra um aspecto das relações entre indígenas e holandeses que tem recebido pouca atenção: a presença de índios do Brasil nos Países Baixos durante o século XVII ${ }^{1}$. Em 1636, por exemplo, o irlandês Bernardo O'Brien del Carpio escreveu para Felipe IV da Espanha que, depois de ter chegado aos Países Baixos em um navio holandês proveniente da Amazônia: "fui a outras cidades da Holanda, como Roterdã, Delft, Haia, onde encontrei muitos portugueses e índios do Brasil que pretendiam que o Estado da Holanda os empregasse em seu serviço"2.

Os estudos referentes à história dos povos indígenas no Brasil são marcados por uma falta de documentação e, ademais, a maioria das fontes disponíveis para os séculos XVI e XVII foi escrita por europeus. Os documentos escritos por índios durante o período do Brasil Holandês destacam-se justamente porque este tipo de documento é tão raro. O folheto é importante, em primeiro lugar,

\footnotetext{
${ }^{1}$ SOUTO MAIOR, Pedro. "Fastos Pernambucanos". Revista do Instituto Histórico e Geográfico Brasileiro. Rio de Janeiro, Vol. LXXV, Tomo 1, 1913, pp. 142-176.

${ }^{2}$ Bernardo O'Brien del Carpio era o filho de um nobre irlandês. Ele tinha participado em expedições para a Amazônia desde 1620. Veja RIBEIRO, Darcy, e MOREIRA NETO, Carlos de Araújo, orgs. A Fundação do Brasil. Petrópolis: Vozes, 1992, pp. 322-327, onde se cita Archivo de Indias, Sevilha, Est.147-caj.5-Leg.21.
} 
por representar um dos poucos textos que expressam a perspectiva dos indígenas do Brasil do século XVII. De fato, Paraupaba foi testemunha da relação entre os índios e os neerlandeses durante 32 anos. $O$ folheto tem sido citado freqüentemente, mas nunca foi republicado por inteiro desde $1657^{3}$.

O segundo aspecto importante do folheto reside na descrição do envolvimento dos holandeses no Brasil, período importante tanto na expansão européia para as Américas, quanto pelo seu impacto nos Países Baixos. O discurso de Paraupaba reflete a percepção que ele tinha dos neerlandeses. Pesquisas históricas recentes sobre as relações entre neerlandeses e ameríndios durante o século XVII têm caracterizado estas relações como um amplo processo de trocas ${ }^{4}$.

$\mathrm{O}$ texto do folheto consiste de duas exposições feitas por Paraupaba para os Estados Gerais, além da tradução de uma carta portuguesa interceptada do Brasil. O primeiro pedido de Paraupaba foi registrado em agosto de 1654 no índice das resoluções do Estados Gerais. Os Estados Gerais constituíam o conselho soberano na República dos Países Baixos Unidos, com sede na cidade de Haia, na corte do Condado da Holanda, onde o congresso do presente Reino dos Países Baixos se reúne. A versão manuscrita do segundo requerimento,

\footnotetext{
${ }^{3} \mathrm{O}$ folheto é citado em RIBEIRO e MOREIRA NETO. A Fundação do Brasil, op.cit., pp. 231-232; MEUWESE, Mark. For the Peace and Well Being of the Country: intercultural mediators and Dutch-Indian relations in New Netherlands and Dutch Brazil, 1600-1664. Tese Ph.D., University of Notre Dame, EUA, 2003, pp. 189, 201, 205-210; POMPA, Cristina. Religião como Tradução: missionários, Tupi e 'Tapuia'no Brasil colonial. Bauru: Edusc, 2003, pp. 208-214; MELLO, José Antônio Gonsalves de. Tempo dos Flamengos [1947]. $3^{\text {a }}$ edição aumentada. Recife: Massangana, 1987, p. 224; BOXER, C. R., The Dutch in Brazil, Oxford: Oxford Univ. Press, 1957, p. 291, MELLO, Evaldo Cabral de. O Negócio do Brasil: Portugal, os Países Baixos e o Nordeste, 1641-1669. Rio de Janeiro: Topbooks, 1998, p. 228. Frans Leonard SCHALKWIJK cita o manuscrito em seu Igreja e Estado no Brasil Holandês, Recife: Fundação do Patrimônio Histórico e Artístico do Pernambuco, 1986, pp. 308-310.

${ }^{4}$ Para a percepção holandesa de América ver SCHMIDT, Benjamin. Innocence Abroad: the Dutch imagination and the New-World, 1570-1670. Cambridge: Cambridge University Press, 2001; MASON, Peter. Deconstructing America: representations of the other. Nova York: Routledge, 1990; e PAGDEN, Anthony. The Fall of Natural Man. Cambridge: Cambridge University Press, 1982. Os processos de troca são o assunto do recente estudo de MEUWESE, For the Peace and Well Being of the Country, op. cit., que traz informações extensas sobre Paraupaba e é recomendado para leitura sobre este assunto. $\mathrm{O}$ autor gostaria de expressar sua gratidão pela contribuição de Mark Meuwese para este artigo. O estudo de POMPA, Religião como Tradução, op. cit., enfoca a religião enquanto processo de troca entre os europeus e ameríndios do Brasil. GALINDO, Marcos. O Governo das Almas: a expansão colonial no país dos tapuia 1651-1798. Tese Ph.D., Universidade de Leiden, 2004, estuda a troca no interior do Nordeste no período posterior ao Brasil Holandês.
} 
datado em abril de 1656, foi preservada, ao contrário do original do primeiro, o qual sobrevive apenas em sua versão impressa ${ }^{5}$.

É difícil comprovar se Paraupaba de fato escreveu as exposições. O manuscrito existente do segundo requerimento foi redigido por um escritor profissional. A correção do nome de Paraupaba na primeira página do manuscrito sugere que ele conferiu o documento depois de escrito antes de assiná-lo. Ainda assim, também é difícil provar que Paraupaba não escreveu os requerimentos. Paraupaba era um escritor experiente: as Minutas Diárias do Alto Conselho da WIC no Recife se referem a vários textos de sua autoria. A correspondência entre brasilianos, como a resposta de Pedro Poti às cartas de Dom Antônio Felipe Camarão, seu parente, aponta um grau relativamente alto de alfabetização entre a população indígena de Pernambuco, Itamaracá e Paraíba. Pedro Poti até empregava um escritor pessoal, a exemplo de muitos altos funcionários da WIC 6 .

Ao escrever sobre os brasilianos, inclusive Paraupaba, que viajaram para os Países Baixos em 1625, J. Laet afirmou: “...nós os vimos freqüentemente nas Províncias Unidas, eles aprenderam nosso idioma, eles sabem escrever e são instruídos nos princípios da religião cristã. Nós temos, de um certo modo, recebido conhecimento destas regiões deles". J. A. Gonsalves de Mello concluiu que os índios em Leiden circulavam no meio universitário ${ }^{7}$.

Aqui o folheto é apresentado na forma de uma tradução portuguesa do texto impresso das exposições de Paraupaba com anotações à margem. A tradução é precedida por uma informação contextual concisa sobre Antônio Paraupaba e os brasilianos ${ }^{8}$.

\footnotetext{
${ }^{5}$ Para as exposições de Paraupaba, ver ASG SR 4846: 7 e 8 de agosto de 1654: 107; ASG SR 3216: 7 e 8 de agosto de 1654: 593, 595.ASG SR 4846: 6 de abril de 1656: 205.

${ }^{6}$ Pedro Souto Maior publicou uma tradução portuguesa das cartas escritas pelo Potiguar Dom Antônio Felipe Camarão a Paraupaba e Poti e a resposta do segundo, publicada como panfleto: P. Pottij, Copye van een Brasilaensen brieff, em "Fastos Pernambucanos", op.cit. MEUWESE, For the Peace and Well Being of the Country, p. 187, cita: "Em meados de fevereiro de 1647, Johannes Engelaer, professor e consolador de doentes dos Brasilianos, pede recompensa para os serviços do seu filho Samuel Engelaer porque este tinha estado a serviço dos Brasilianos durante 21 meses e tinha sido usado como escritor para o Regedor Pedro Pottij." (OWIC 71: 17 de fevereiro de 1647)

${ }^{7}$ J. de Laet, L'histoire du Nouveau Monde é citado em MELLO, Tempo dos Flamengos, op. cit., p. 198.

${ }^{8}$ Eu expresso a minha gratidão a Edyna Rocha Cavalcanti por sua ajuda e a Mariana Françozo pela tradução e revisão de meu texto. Eu gostaria neste momento também de agradecer ao Professor John M. Monteiro pelo seu apoio à minha pesquisa histórica.
} 


\section{Brasilianen}

Em seus textos, os holandeses adotaram a divisão entre os povos de língua Tupi ao longo da costa e os Tapuia, os "não-Tupi" do interior. Os Tupi foram nomeados Brasilianen ("Brasileiros" ou "Brasilianos") e esses eram vistos como civilizados ao contrário dos "bárbaros" Tapuia. Assim, por exemplo, a aliança dos holandeses com os Tarairiu de Janduí foi marcada pela representação do caráter exótico destes Tapuia. No entanto, John Monteiro aponta para a construção histórica da unidade Tupi no século XIX por historiadores como Varnhagen e estudos recentes de Cristina Pompa e Marcos Galindo sugerem que esta divisão entre Tapuia e Tupi nem sempre se mostrava tão clara. Afinal de contas, a chegada dos europeus resultou em migrações substantivas e outros rearranjos da população indígena no nordeste do Brasil ${ }^{9}$.

Nos relatos do século XVI, os Potiguar eram considerados dominantes ao longo da costa que ia de Pernambuco ao Maranhão. Duarte Coelho, o fundador de Pernambuco, estabeleceu boas relações com eles, porém estas se deterioraram já em meados do século XVI. Os Potiguar na Paraíba e no Rio Grande foram derrotados entre 1589 e 1599, a despeito de sua resistência feroz com armas de fogo compradas dos franceses. Parte da nação Potiguar, encabeçada pelo pai de Dom Antônio Felipe Camarão, se aliou aos portugueses nestas guerras. Outros fugiram no início do século XVII para o Ceará e Maranhão. Em sua carta para Camarão a 31 de outubro de 1645, a qual também foi publicada como folheto, Pedro Poti refere-se a esta divisão na nação dos Potiguar: "Não, Philippe, vós vos deixas illudir; é evidente que o plano dos scelerados Portugueses não é outro sinão o de se apossarem deste paíz, e então assassinarem ou escravizarem tanto a vós como a nós todos"10.

\footnotetext{
${ }^{9}$ MONTEIRO, John M. Tupis, Tapuias e Historiadores, Estudos de História Indígena e do Indigenismo. Tese de Livre Docência, Unicamp, 2001, pp. 12-35. Para as relações entre os holandeses e os 'Tapuia' ver: TEENSMA, B. N. "Roelof Baro's Taraririú-monument". Yumtzilob tijdschrift voor de America's. Leiden, XI.3, 1999, pp. 351-373; e BOOGAART, E. van den. "'Infernal Allies': The Dutch West India Company and the Tarairiu, 1630-1654". In: Johan Maurits van Nassau-Siegen, 1604-1679: A Humanist Prince in Europe and Brazil. org. Boogaart, E. van den et alii. Haia: Johan Maurits van Nassau Stichting, 1979. Ver POMPA, Religião como Tradução, op.cit., pp. 133-149, para a migração e para as relações com os holandeses, pp. 240-256; e GALINDO, O Governo das Almas, op.cit., pp. 41-80, para a migração indígena no Nordeste do Brasil.

${ }^{10}$ Uma descrição concisa dos Potiguar se encontra em HEMMING, John. Red Gold. Londres: Macmillan, 1978, pp. 160-182. A identificação do Potiguar está baseada principalmente em representações portuguesas contemporâneas como as de Frei Vicente do Salvador, His-
} 
Os Potiguar faziam parte do conjunto que os holandeses identificavam como brasilianos. Da perspectiva holandesa, uma distinção importante entre os brasilianos e os Tapuia era que os primeiros conduziam uma vida relativamente sedentária em aldeias. Essas aldeias tinham origem no projeto de civilizar os índios sob a direção de missionários católicos. As aldeias tinham um papel importante na defesa contra invasores indígenas e também serviram de fonte de mão de obra para a economia local. A conquista da Paraíba em 1634 resultou no estabelecimento do domínio holandês sobre uma parte grande da população brasiliana. A WIC adotou a fórmula portuguesa do governo dos brasilianos em aldeias ${ }^{11}$.

\section{Antônio Paraupaba}

Antônio Paraupaba provavelmente partiu do Brasil em primeiro de agosto de 1625 com a frota do Almirante Boudewijn Hendricxsz, junto com seu pai Gaspar Paraupaba. De Laet menciona os nomes de Marzial, Takou, Ararova e Matauve, enquanto Hessel Gerritsz se refere aos índios embarcando com esta frota e chegando nos Países Baixos como Andreus Fransisco, Antony Guirrawassauay, Antony Francisco e Lauys Caspar. Apesar da grafia dos nomes indígenas em arquivos neerlandeses se mostrar extremamente incerta, dois nomes são inconfundíveis: Pedro Poti e o "velho" Gaspar Paraupaba, pai de Antônio. Na Holanda, a WIC assumiu a instrução dos índios da Bahia da Traição como um investimento de longo prazo. Alguns dos índios ficaram em

tória do Brasil, e Frei Calado. Frei Manoel Calado é uma fonte contemporânea muito importante uma vez que ele testemunhou muitos eventos entre 1630 e 1645 que ele descreveu no seu $O$ Valeroso Lucideno. Varnhagen dedica atenção especial a Camarão no seu Historia Geral do Brasil. Alguns dos Potiguar uniram-se com os portugueses contra os franceses e os Tupinambá entre 1612 e 1615 no Maranhão, outra indicação da complexidade da identidade Potiguar. MONTEIRO, Tupis, Tapuias e Historiadores, op.cit., pp. 62-70, contém uma abordagem dos Potiguar da perspectiva da etnogênese. Para a citação de Poti: SOUTO MAIOR, "Fastos Pernambucanos", op.cit., pp. 142-160.

${ }^{11}$ Sobre as aldeias, ver POMPA, Religião como Tradução, op.cit., pp. 57-84. Pompa não vê as aldeias como uma forma tradicional de habitação indígena, mas como um projeto de integração onde a proteção contra traficantes de escravos era um dos incentivos para a participação indígena. Ver também MEUWESE, For the Peace and Well-Being, pp. 152-157. 
Groningen, outros em Amsterdã. Paraupaba, no entanto, não deixou nenhum rastro da permanência dele nos Países Baixos entre 1625 e $1631^{12}$.

Paraupaba e Poti voltaram para o Brasil em 1631, onde atuaram principalmente como intérpretes no intuito de recrutar aliados índios para os Holandeses. Nos relatos, Paraupaba aparece como um dos brasilianos educados nos Países Baixos. De Laet, por exemplo, o menciona como intérprete para Arciezewski e Stachouwer nas negociações com os Tapuias de Janduí no Rio Grande, em outubro de $1634^{13}$. Já o relatório de Adriaen van der Dussen cita Paraupaba como capitão da aldeia de Aabaú em Goiana em 1639.

Os primeiros resultados da missão nas aldeias mostraram-se animadores, tendo o Classis Reformado começado em 1640 com a nomeação de brasilianos como professores. Entretanto, o seu desenvolvimento posterior foi decepcionante. Os holandeses chegaram ao ponto de seriamente contemplar a possibilidade de separar as crianças dos brasilianos para educá-los em uma escola especial. O Alto Conselho repreendeu várias vezes Poti e Paraupaba. Em 1644, por exemplo, ao se referir a Paraupaba, escreveu: "na verdade, acreditamos que Pieter Poti e Antônio Paripaba cuja educação na Holanda custou tanto dinheiro à Companhia, são mais perversos e mais selvagens na maneira de viver do que os outros Brasilianos". Parece que os brasilianos tinham seus próprios planos ${ }^{14}$.

Paraupaba viajou para os Países Baixos pela segunda vez em 1644, acompanhando uma delegação brasiliana que, por sua vez, acompanhava Maurício de Nassau em seu regresso à Europa, após ter servido sete anos como Governador Geral no Brasil. Naquela altura, os funcionários da WIC ainda sentiam

\footnotetext{
${ }^{12}$ A descrição pode ser achada em LAET, Joannes de. Historia ou Annaes dos feitos da Companhia Privilegiada das Indias Occidentaes, desde o seu começo até ao fim do anno de 1636. Tradução José Hygino Duarte Pereira e Pedro Souto Maior. 2 vols. Rio de Janeiro: Biblioteca Nacional, 1916, Vol. 1, pp. 96-97. A referência para Hessel Gerrits, um cartógrafo que publicou os nomes, pode ser achado em MEUWESE, For the Peace and Well Being, op.cit., pp. 87-90 e MELLO, Tempo dos Flamengos, op.cit., p. 198.

${ }^{13}$ LAET, Historia ou Annaes dos Feitos, op.cit., Vol 2, pp. 296, 460. De Laet refere no seu, L'histoire du Nouveau Monde de 1640 aos moradores da Baía da Traição como Tiguares. Na tradução de Pedro Souto Maior da Historia ou Annaes dos feitos encontra-se "Brasilianen" traduzido por "índios". Nos "Fastos Pernambucanos", p. 146, também há referência a um dos índios como sendo Tiguar.
}

${ }^{14}$ Veja MELLO, Tempo dos Flamengos, op.cit., pp. 214-224. 
o impacto provocado pela rebelião de índios Potiguar no Ceará no início de 1644, que matou muitos neerlandeses, inclusive Gideon Morris, um dos seus defensores mais fortes ${ }^{15}$.

Em outubro desse ano, a delegação brasiliana conseguiu uma audiência em Amsterdã na reunião dos Senhores XIX. O relato dos deputados dos Estados Gerais afirma o seguinte: "Os deputados dos Brasilianos obedientes a este Estado, que chegaram em julho passado com Conde Mauricio de Nassau, pediram essa reunião para serem libertados porque sempre foram leais à Companhia e provaram o serviço leal em vários empreendimentos de guerra. Foi aprovado que se desse a eles uma carta de patente e que fossem libertados e mantidos como Neerlandeses enquanto se mantivessem obedientes a este Estado. Também seriam enviados professores para lá, para instruir os Brasilianos nas suas aldeias na religião cristã e foram instituídos juizes entre eles para administrar justiça como pode ser visto na cópia anexa"16.

No dia 24 novembro de 1644, a embaixada recebeu em Amsterdã um documento oficial dos Senhores XIX que declarava os privilégios deles no Brasil Holandês. Paraupaba deve ter feito uma viagem de regresso rápida. Os brasilianos organizaram uma assembléia em Itapesserica e, no dia 30 de março de 1645, apresentaram ao Alto Conselho no Recife a carta dos Senhores XIX, junto com um documento que resultou desta assembléia no qual os brasilianos propuseram conselhos de "vereadores", listando os nomes de muitos brasilianos, inclusive os de Paraupaba e Poti. A partir de 1636, a WIC havia introduzido estes conselhos nas municipalidades portuguesas já estabelecidas, porém não nas aldeias. Três regedores tomaram posse como vereadores em 12 de abril de 1645 e Carapeba foi escolhido para guardar e vigiar uma cópia do documento dos Senhores XIX. Os brasilianos voltaram às suas aldeias depois de terem recebido alimentos, panos e dinheiro, para eles e para os seus vinte capitães. No dia 5 de maio de 1645, os membros da delegação enviaram alguns quintais

\footnotetext{
${ }^{15}$ Para os eventos no Ceará ver MELLO, Tempo dos Flamengos, cit., p. 209. Para um relato mais detalhado dos eventos que conduziram à assembléia indígena ver MEUWESE, For the Peace and Well Being, op.cit., pp. 171-183.

${ }^{16}$ MEUWESE, For the Peace and Well Being, op.cit., pp. 176-177, citando DNA ASG 1.04.015757.
} 
de pau-brasil ao Alto Conselho, em gratidão pela recepção amistosa que eles tinham recebido nos Países Baixos ${ }^{17}$.

Paraupaba foi nomeado Capitão e Regedor do Rio Grande em junho de 1645. Já no dia 3 de julho, ele redigiu um pedido exigindo a libertação de todos os escravos brasilianos. Isto demonstra que a escravidão persistia enquanto assunto relevante para os brasilianos ainda em 1645. Se o legado huguenote francês explica em parte a insistência da WIC em proibir a escravização de brasilianos, esta política não se mostrava muito popular entre a população local de portugueses e holandeses ${ }^{18}$. Em seu relatório de 1639, Van der Dussen escreveu: "Vão para o trabalho como forçados e de má-vontade, mas com aguardente consegue-se tudo deles [...] Entretanto, como os negros são poucos agora no país, os indígenas são mais procurados para o trabalho do que anteriormente, o que eles bem percebem e não querem aceitar trabalho algum se não lhes paga adiantadamente, e tendo ocasião fogem e o senhor perde o seu pano". De fato, o número de referências à escravidão indígena sugere que a contribuição dos índios para a economia tenha sido subestimada na bibliografia, talvez em função da remuneração deles ser paga in natura e portanto sem registro, ou em função do caráter clandestino da escravidão indígena ${ }^{19}$.

A situação mudou radicalmente com a erupção de hostilidades em 1645. Em julho, índios Tapuias massacraram moradores portugueses em Cunhaú. Os moradores se vingaram em agosto, chacinando os índios aliados aos holandeses que tinham se rendido em Serinhaem e Casa Forte. Na ocasião, Poti escreveu: “...a tirania, recentemente perpetrada por André Vidal, depois que

\footnotetext{
${ }^{17}$ Pedro Souto Maior realçou a assembléia brasiliana de 1645 em "Fastos Pernambucanos" como a primeira expressão política de uma identidade política americana. A posição dos brasilianos no Brasil holandês é bastante excepcional. A maioria das relações de indígenas com neerlandeses no século XVII não admitia nenhuma forma de participação institucional por ameríndios na administração. A importância que os brasilianos conferiram ao documento emitido pelos Senhores XIX em 1644 referente aos direitos e privilégios da população brasiliana, é ilustrada pela cópia nova que o Alto Conselho no Recife emitiu ao regedor Carapeba no dia 28 de outubro de 1645, porque a cópia dele tinha sido perdida em Itamaracá durante as batalhas de setembro de 1645. (OWIC No. 70.) Quintal é uma antiga unidade de medida de peso, equivalente a quatro arrobas.

${ }^{18}$ Para a carta de Paraupaba ver OWIC 70: 7 de junho de 1645

${ }^{19}$ MELLO, José Antônio Gonsalves de, org. Fontes para a História do Brasil Holandês. Recife: Fundação Pró-Memória, 1981, p. 183. Para a missão holandesa e sua relação com a França, ver SCHALKWIJK, Igreja e Estado no Brasil Holandês, op.cit., pp. 16-18, 36, 82, 164-165.
} 
bom quartel foi concedido, para nossos irmãos em Serinhain [...] mas de qual meu irmão Antoni no Rio Grande levou vingança boa”. Paraupaba teve um papel importante no massacre de portugueses no Rio Grande a 3 de outubro de 1645, perto de Uruauassu: "na qual acharam passante de duzentos Brasilianos bem armados com Antônio Paraupaba escaramuçando em um cavalo [...] os flamengos despiram nus aos ditos moradores, e os mandaram pôr de joelhos [...] e logo chamaram aos Brasilianos para os matar." Este relato por Lopo Curado, citado por Calado no seu Valeroso Lucideno, teve um papel importante na beatificação, pelo Papa João Paulo II, de algumas das vítimas deste massacre, no dia 5 de março de $2000^{20}$.

Paraupaba permaneceu ativo no Rio Grande, executando uma missão especial no Ceará em 1648. Pedro Poti e Paraupaba pressionavam o Alto Conselho constantemente por armas e dinheiro porém seus esforços foram em vão. A derrota na segunda batalha de Guararapes a 2 de fevereiro de 1649 esmagou todas as esperanças dos brasilianos aliados com os Holandeses. Poti foi capturado e, embora o Alto Conselho tenha feito esforços para ajudá-lo, graças à pressão dos brasilianos, eles não conseguiram libertá-lo. Ele foi substituído como regedor por Caspar Cararu ${ }^{21}$.

O problema que surgiu em relação a Carapeba proporciona uma ilustração importante das relações entre os neerlandeses e os regedores ameríndios. Listrij, diretor dos brasilianos, informou no dia 24 de setembro de 1649 que Carapeba tinha matado um Alferes em uma disputa por uma moça. Carapeba escreveu a Listrij que ele considerou o assunto uma questão militar dentro de seu próprio foro. Os brasilianos não estavam dispostos a julgá-lo, porém eles também não o reconheciam mais como regedor. OAlto Conselho ofereceu para Carapeba a escolha

\footnotetext{
${ }^{20}$ Para o comentário de Poti veja SOUTO MAIOR, "Fastos Pernambucanos", cit. Para a descrição do massacre, ver CALADO, Frei Manoel. O Valeroso Lucideno e Triunfo da Liberdade [1648]. 2 vols. Recife: Cooperativa Editora de Cultura Intelectual, 1942, Vol. 2, pp. 149-155. Antônio escreveu duas cartas ao Alto Conselho, primeiro no dia 28 de setembro, mais tarde em 10 de outubro de 1645, que confirma a lealdade dos brasilianos no Rio Grande, sem recorrer ao massacre (OWIC 71). Para um descrição neerlandesa dos eventos, ver NIEUHOF, Johan. Memorável Viagem Marítima e Terrestre ao Brasil. Tradução de Moacir N. Vasconcelos. São Paulo: Martins, 1942, pp. 157-158, 178-183, 227-228.

${ }^{21}$ OWIC 71: 4 de dezembro de 1645: Comitiva dos Capitães dos Brasilianos sobre armas; OWIC 73: 13 de dezembro de 1647: missiva de Pedro Poti sobre falta de pagamento; 12 de setembro de 1648, OWIC 73,: 26 de outubro de 1649: Antônio Paraupaba pede pagamento de brasilianos. Veja também MEUWESE, For the Peace and Well Being, op.cit., pp. 194-195.
} 
entre o banimento e o julgamento. Ele escolheu o segundo. Depois de consultar o Conselho da Justiça, o Alto Conselho deliberou que, como um índio, Carapeba deveria ser julgado pela lei militar. A 2 de novembro de 1649, o tribunal militar condenou Carapeba a "morrer pela espada no lugar habitual". O Alto Conselho, receoso de uma eventual reação dos índios, baniu Carapeba para Fernando de Noronha. As deliberações sobre o estado legal de Carapeba, a delegação subseqüente do assunto para a corte militar e a intervenção em sua sentença, mostram claramente o quanto permaneceu delicada e difícil a relação oficial dos holandeses com os brasilianos, mesmo depois de 19 anos de experiência ${ }^{22}$.

Como o único remanescente dos três regedores originais, Paraupaba assumiu a liderança principal dos "Brasilianos Holandeses" e conduziu as tristes sobras de sua nação ao exílio na Serra de Ibiapaba, na fronteira entre Maranhão e Ceará, durante os últimos dias do Brasil Holandês. De lá, ele embarcou para os Países Baixos. A partida de Paraupaba foi registrada no diário de um funcionário da WIC. Paraupaba subiu a bordo de um navio da WIC com sua esposa e três crianças no começo de fevereiro de 1654. O mesmo relato registra que o pai dele, Gaspar Paraupaba, que também tinha visitado a República holandesa em 1625 e que tinha servido como um intérprete para a WIC no Ceará de 1649 a 1654, dramaticamente rejeitou uma oferta para acompanhar seu filho à Europa porque "ele quis terminar a vida dele na selva entre a Nação dele, em lugar de velejar para a Holanda". Paraupaba chegou nos Países Baixos para apresentar seu primeiro requerimento em agosto de 1654 na cidade de $\mathrm{Haia}^{23}$.

\footnotetext{
22 "Recebi e li uma missiva datada de 22 [de setembro de 1649] escrita pelo Tenente Coronel M:V: van de Wal na Ilha Tamaraca na cidade Schoppe onde ele avisa que o Regidor Domingos Ferdinandes Carapeba no dia 18 deste mês, enquanto estando altamente bêbado, amarrou para uma estaca um Alferes dele chamado de Salvador, quem ele acusou de querer escapar com uma das moças empregadas dele que estava fugida, e que o regidor tinha três vezes apunhalado Salvador, que tinha sido abatido por uma bala atirada por Carapeba, o que causou a morte dele. OWIC 73: 24 de setembro de 1649: Carta Listrij; 9 de setembro: Carta Listrij a Carapeba; 27 de outubro: caso de deliberação Carapeba: 28 de outubro: relatório de Conselho da Justiça sobre Carapeba; 2 de novembro de 1649: veredito do tribunal marcial: pena de morte, banimento de Carapeba para Fernando de o Noronha pelo Alto Conselho.

${ }^{23}$ Veja para eventos no Ceará KROMMEN, Rita. Mathias Beck und die Westindische Kompagnie: Zur Herrschaft der Niederländer im kolonialen Ceará (Arbeitspapiere zur Lateinamerika Forschung II-01). Colonha: Universität zu Köln, 2001. Mathias Beck conta como os holandeses foram salvos dos Potiguar enfurecidos, pelos portugueses em 1654. Sobre a partida de Paraupaba, ver MEUWESE, For the Peace and Well Being, op.cit., p. 205. A menção no diário do funcionário está em IBOLD, Frank; JÄGER, Jens, e KRAACK, Detlev, orgs. Das "Memorial und Jurenal" des Peter Hansen Hajstrup (1624-1672). Neumünster: Wachholtz Verlag, 1995, p. 108)
} 
A atuação pública de Paraupaba é muito bem documentada nos arquivos mas a vida pessoal dele continua um mistério. É curioso notar que a ortografia de seu nome no manuscrito aparece como Paräupába. Em tupi, o nome Paraupaba é ligado à água: Pará + upaba = laguna, ou um rio formado por lagunas. A variante Paraopeba existe em Minas Gerais, atribuído a um dos tributários do rio São Francisco porque este rio supostamente se originou em uma laguna. Não se pode determinar nem o local de seu nascimento, nem o de sua morte. A referência a Paraupaba na folha de rosto do folheto, que declara "foi durante sua vida", indica que ele morreu antes da publicação em 1657. O pedido de ajuda feito pela viúva dele, Paulina, em 1656, sugere que ele morreu nos Países Baixos entre abril e julho daquele ano. Assim, é provável que Paraupaba tenha morrido antes de 7 de julho de 1656: "Sendo lido nesta reunião, o pedido de Paulina Paraupaba, nascida no Brasil, a esposa de Antônio Paraupaba, Regedor anterior da nação Brasiliana no Brasil, que pede um subsídio para alimento de sua família. Depois de deliberado, é aprovado e acordado que se pague para a suplicante a soma de 50,--florins, cuja ordem de pagamento será enviada a ela. Para alimento adicional ela é dirigida aos Diretores da Companhia das Índias Ocidentais da Câmara de Amsterdã "24.

De qualquer modo, pode-se afirmar que Antônio Paraupaba foi uma figura notável. Viajou do Brasil para os Países Baixos pelo menos três vezes, além das viagens dele para o Ceará e Ibiapaba. Hábil com caneta, cavalo e espada, era um homem que gostava de beber, mas sabia também citar sua Bíblia.

\footnotetext{
${ }^{24}$ ASG SR 4846: 7 de julho de 1656. Meuwese parece sugerir que Paraupaba ainda estava vivo mas o aparecimento de Paulina em vez de Paraupaba, sugere que ele já tinha morrido, também porque ela é dirigida ao WIC. Paulina volta entretanto aos Estados: ASG SR 3216: 12 de outubro de 1656: "Sendo lido nesta reunião, o pedido da viúva do recente Antônio Paraupaba, durante a vida dele Regedor anterior de uma Companhia de Brasilianos no Brasil, pedindo, para o alimento de sua família, a continuação do pagamento de dois cavaleiros com os quais seu marido tinha sido premiado para ganhar da Companhia do Senhor van Broeckhuijsen na guarnição em 's Hertogenbosch. Depois que deliberação seja aprovada e compreendida para dirigir a suplicante por este meio aos Senhores ' Gecommitteerde Raden' da Província de Holanda que administra a Companhia de Broeckhuijsen.” MEUWESE, For the Peace and Well Being, op.cit., pp. 210-214.
} 


\section{A tradução ${ }^{25}$}

Qualquer tradução tem a marca do seu tempo. Assim, aquela que apresentamos nas páginas que se seguem contém escolhas que devem ser explicadas. O primeiro texto, bem como um trecho do segundo (aquele em que Paraupaba cita Pedro Poti), já haviam sido traduzidos numa valiosa versão de Pedro Souto Maior, publicada em 1912. Escolhemos adaptar alguns trechos desta tradução de Souto Maior, de modo a evitar a confusão de três registros temporais diferentes: o holandês de Paraupaba no século XVII, o português de Souto Maior no início do XX e o nosso, no começo do XXI. Portanto, para apresentar uma tradução de acordo com o português corrente, foi preciso interferir em algumas das opções de construção de frase de Souto Maior, que eram correntes há cem anos mas hoje não o são mais; tratou-se também de modernizar a ortografia e a acentuação das palavras, bem como rever a pontuação à luz do panfleto original. Além disso, notamos que Souto Maior traduziu a palavra "Brasilianen" pelo termo genérico "índio". Optamos por corrigir esta imprecisão usando o designativo "brasiliano".

A palavra neerlandesa Remonstrantie, proveniente do francês remontrance, indica uma cultura "parlamentar". No discurso neerlandês da época, isso implicava numa exposição crítica e num requerimento solicitando uma resolução favorável. "Representação" pareceu-nos a melhor tradução.

Também foram incluídas as páginas da segunda exposição que foram omitidas na tradução de Souto Maior. O panfleto que Hondius publicou consiste em 20 páginas impressas em quarto. Souto Maior publicou somente duas páginas e meia das treze páginas impressas da segunda exposição do Paraupaba. Essa exposição se destaca por trazer um relato histórico das relações entre os Potiguar da Bahia de Traição e os holandeses no período 1625-1654.

\footnotetext{
${ }^{25}$ A autoria da tradução ora apresentada é de Lodewijk Hulsman com o auxílio de Mariana Françozo.
} 


\section{Thee Gerithepoen}

Remonftrantien $O F T E$

\section{VER T O GEN,}

\section{SDrrgegeben}

\section{Aen hare Ho:Mo:de Heeren Staten Generael der Vereenighde Nederlanden.}

\section{Door}

\section{A NTHONIO PAR äUPá B A,}

In fynleven geveeft Regidoor vande Brazilianen inde Capitania ven Rio Grande: Ende met het laetfle ongeluckigh verlies vau Brazyl, vande gantfcibe Braziliaenfche Natie afgefonden; aen hare Ho:Mo:om derfelver Natie abermelycken en jammer ligck in toeflaur te vertonen, ende met eenen buipe ende byftant te verfoecken.

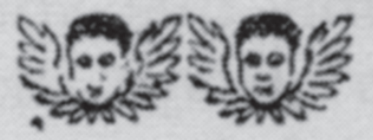

$$
\text { In'SGRAVEN-HAGE, }
$$

Gedruckt by HENRICUS HONDIUS, woonende inde Hofttraet, incic ricuwe Konft-en-Boeck-Druckery. 1657 . 


\section{TRANSCRIÇÃO DO DOCUMENTO}

\section{CAPA:}

Dois distintos requerimentos ou exposições entregues $a V^{\text {as }}{ }^{\text {Ex. }}{ }^{\text {as }}$ os Estados Gerais dos Países Baixos Unidos por Anthonio Paräupába, que em vida foi Regedor dos Brasilianos na capitania do Rio Grande ${ }^{(1)}$. Enviado a V. ${ }^{\text {as }}$ Ex. ${ }^{\text {as }}$ como representante da nação Brasiliana, depois da infeliz perda recente do Brasil, para expor a situação lamentável e deplorável dessa mesma nação e para pedir ajuda e assistência. ${ }^{(2)}$ 's Gravenhage (Haia). Impresso por Henricus Hondius, morador da Hoffstraet, na nova tipografia Arte e Livros. 1657. (panfleto KB [7871]) $)^{(3)}$

\footnotetext{
(1) A tradução mantém a ortografia do nome de seu autor original do folheto. À parte a tradução, a ortografia Antônio Paraupaba será usada. 'Regidoor' no texto neerlandês corresponde ao Regedor em português, uma posição municipal na administração colonial Portuguesa, instituída pelo governo Espanhol. Os regedores originalmente representaram a população local, como os 'escabinos', vereadores neerlandeses, mas ao final do século XVI, a função se tornou uma ocupação para toda vida que às vezes era leiloada. Os brasilianos escolheram este título provavelmente porque era vitalício.A Assembléia indígena de 1645 resultou na nomeação de três Regedores: Antônio Paraupaba no Rio Grande do Norte, Pedro Poti na Paraíba e Domingo Fernandes Carapeba em Itamaracá e Goiana. (Recopilación de Leyes de los Reynos de las Indías, Vol. 2 33-35, 40, 210 211, 441, 550; SOUTO MAIOR, Pedro. “Assembléia de Índios em Pernambuco de 1645”. Revista do Instítuto Histórico Arqueológico Pernambucano, Recife, 79, 1910, pp. 61-77).Na tradução do Pedro Souto Maior se encontra "Brasilianen" traduzido pelo termo genérico "índios". O nome brasilianos será usado aqui como uma tradução de Brasilianen no holandês para indicar a população de fala Tupi do litoral que morava em aldeias. A tradução correta seria "brasileiro" porque "Braziliaan" em holandês significa um morador do Brasil hoje em dia. "Brasileiro", na época, descrevia alguém ativo na coleta do pau brasil, uma atividade importante para muitos índios ao longo da costa brasileira nos séculos XVI e XVII e a fonte da presente indicação "brasileiro" para um nacional do Brasil. Os europeus, assim, davam o nome brasileiro para os índios do Brasil, para depois tomar este nome como denominação para todo mundo nascido no Brasil, salvo a população indígena. (GALINDO, O Governo das Almas, op.cit., pp. 43-44; VARNHAGEN, Historia Geral do Brasil, op.cit., vol.1 101).

${ }^{(2)}$ A recente perda se refere à rendição de Recife em janeiro de 1654.

${ }^{(3)}$ Henricus Hondius tinha vivido em Cabo Santo Agostinho no Brasil, onde há um registro dele como lavrador no engenho Garapu (MELLO, Tempos dos Flamengos, op.cit., p. 237).
} 


\section{PRIMEIRAEXPOSIÇÃO DE PARÄUPÁBA, EM $1654^{(4)}$}

Altos e Nobres Senhores, etc.Antonio Paräupába, ex-Regedor dos Brasilianos no Rio Grande faz ver com todo o respeito $a V{ }^{\text {as }}$ Ex. ${ }^{\text {as }}$ que toda a nação Brasiliana (ainda não há muito tempo habitando aquela região do Brasil e obedientes ao governo deste Estado até a última conquista feita pelos perjuros Portugueses), têm vivido e perseverado até agora como súditos bons e firmes na sua fidelidade para com este Estado e a Religião Reformada de Cristo, a única verdadeira. Sendo por isso o suplicante enviado a $V .{ }^{\text {as }}$ Ex. ${ }^{\text {as }}$ por esta nação que se refugiou com mulheres e crianças em Cambressive no sertão além do Ceará, a fim de escapar aos ferozes massacres dos Portugueses, para asseverar a $V^{\text {as }}{ }^{2}{ }^{\text {as }}{ }^{\text {e }}$ em nome destas infelizes almas, não somente a constância de sua fidelidade, como também que procuraram a sua subsistência pelo tempo de dois anos, nos sertões, no meio de animais ferozes, e mesmo ainda mais procurarão, conservando-se à disposição deste Estado e fieis à Religião Reformada que aprenderam e praticam, contanto que possam esperar auxílio e socorro de $V .{ }^{\text {as }}$ Ex. as ${ }^{(5)}$ Faltando esse auxílio, este povo terá necessariamente de cair afinal nas garras dos cruéis e sanguinários Portugueses, que desde a primeira ocupação do Brasil têm destruído tantas centenas de

\footnotetext{
(4) $\mathrm{O}$ manuscrito do primeiro requerimento de Paraupaba ainda não foi achado, embora tenha deixado rastros na administração dos Estados Gerais. O requerimento estava na ordem do dia a 6 de agosto de 1654. O conselho subscreveu à resolução dos Estados de Holanda e recomendou que Paraupaba fosse designado a um posto militar. No dia seguinte, recomendou-se que o caso de Paraupaba fosse resolvido pelo conselho do 'Gecommitteerde Raden'. (ASG SR 4846: 7 e 8 de agosto de 1654: 107; ASG SR 3216: 7 e 8 de agosto de 1654: 593, 595).

${ }^{(5)}$ Cambressive é uma referência à Serra de Ibiapaba. O nome Cambressive provavelmente é uma referencia à área no norte da França onde Calvino nasceu. Ibiapaba era importante para muitos povos indígenas no nordeste e norte do Brasil como um refúgio migratório. O jesuíta Antônio Vieira registrou em 1660 o choque dos jesuítas ao achar uma comunidade ameríndia que usava papel veneziano para escrever e que possuía bíblias protestantes. Vieira culpou os brasilianos de Pernambuco por transformarem Ibiapaba na "Genebra" do Brasil, em outra alusão a Calvino. Vieira escreveu: “... eram verdadeiramente aquelas aldeias uma composição infernal, ou mistura abominável de todas as seitas e todos os vícios, formada de rebeldes, traidores, ladrões, homicidas, adúlteros, judeus, hereges, gentios, ateus..." Vieira ainda descreveu a reação dos índios aos jesuítas que falavam no assunto de Inferno: "Mande ao Inferno, diziam, aos índios que o mataram, mas a nós, que lhe não fizemos nenhum mal, porque nos manda ao Inferno sem razão?" Vieira escreveu então: "Outras muitas coisas diziam, que é certo lhas não ensinaram os hereges, senão o Demônio por si mesmo". (VIEIRA, Antônio, S.J. Obras escolhidas. Vol. V. Org. António Sérgio e Ernâni Cidade. Lisboa: Sá da Costa, 1951, pp. 72-134) Boxer vê Cambressive como um sinal de que a missão protestante para os índios durante o Brasil holandês teve mais êxito do que os missionários pensaram. A linguagem de Paraupaba seguramente está repleta de referências Bíblicas. O relato de Vieira pode ser parcial, mas ainda assim indica que Cambressive não era o tipo de comunidade que os pastores reformados aprovariam. (The Dutch in Brazil, op.cit., p. 136)
} 
milhares de pessoas da sua nação. Especialmente depois que procurou a proteção das armas deste Estado e adotou o verdadeiro culto divino, e que agora, se for abandonado, terá de pagar penitência sendo completamente extirpado. Este povo não pode acreditar que $V^{\text {as }}{ }^{\text {a }} x^{\text {as }}$ o recompensem dessa forma por seus fiéis serviços, e tantas e tão longas misérias, fome e massacres; ${ }^{(6)}$ nem que permitam que estes que foram uma vez trazidos ao conhecimento da verdadeira religião se retirem dela e que seja cortado o caminho que lhes apontaram para 0 Reino de Jesus Cristo; nem que deixem que [eles] recaiam na selvageria entre as feras nos sertões bravios. Isto dificilmente se justificaria perante o Grande e Todo Poderoso Deus, que é contra os que enterram a sua libra com medo de a colocar na usura. ${ }^{(7)}$ Portanto confiamos firmemente que $V^{\text {as }}{ }^{2} x^{\text {as }}$ (que sempre se mostraram como verdadeiros pais e defensores dos oprimidos e desamparados, e sinceros paladinos da verdadeira Igreja de Deus) mandarão o mais depressa possível para lá o socorro suficiente para a subsistência da infeliz nação dos Brasilianos e para a conservação da Igreja Cristã Reformada, a única verdadeira. ${ }^{(8)} E$ como o suplicante, deixando pai e mãe, mulheres e filhos, parentes e tudo o mais, trazendo apenas

\footnotetext{
(6) Paraupaba usa o argumento do serviço leal dos índios brasilianos que reivindicavam os direitos deles como súditos dos Estados Gerais como confirmado na carta patente de 24 de novembro de 1644.

(7) $\mathrm{O}$ segundo argumento de Paraupaba é a responsabilidade dos Estados Gerais pela propagação e alimento da religião Reformada. Para ilustrar isto, ele usa a parábola dos talentos escondidos. Mateus 25 (Nova Versão Internacional) "Por fim veio o que tinha recebido um talento e disse: 'Eu sabia que o senhor é um homem severo, que colhe onde não plantou e junta onde não semeou. 25 Por isso, tive medo, saí e escondi o seu talento no chão. Veja, aqui está o que lhe pertence'.26 O senhor respondeu: 'Servo mau e negligente! Você sabia que eu colho onde não plantei e junto onde não semeei? 27 Então você devia ter confiado o meu dinheiro aos banqueiros, para que, quando eu voltasse, o recebesse de volta com juros." Lucas 19 (Nova Versão Internacional) 22 "O seu senhor respondeu: 'Eu o julgarei pelas suas próprias palavras, servo mau! Você sabia que sou homem severo, que tiro o que não pus e colho o que não semeei. 23 Então, por que não confiou o meu dinheiro ao banco? Assim, quando eu voltasse o receberia com os juros. 24 E disse aos que estavam ali: 'Tomem dele a sua mina e dêem-na ao que tem dez'.'”ste argumento é curioso porque a interpretação de intendência, tão familiar hoje, era, aos olhos de muitos católicos ibéricos, uma legitimação controversa feita por hereges protestantes para a usura, um ingrediente essencial do mercado financeiro da República. As traduções modernas da Bíblia evitam a palavra "usura" que se encontra nas traduções neerlandesas e inglesas da época.

${ }^{(8)} \mathrm{O}$ papel dos Estados Gerais como protetores das Igrejas se refere a uma discussão antiga nos Países Baixos. "Paladinos" é a tradução de "Voedster-Heeren", literalmente "Senhores alimentadores", um conceito referente à Confissão Bélgica art. 36 sobre a relação entre Igreja e Estado. Um argumento realmente sofisticado, portanto. (SCHALKWIJK, Igreja e Estado no Brasil Holandês, op.cit., p. 311)
} 
consigo para o consolarem em sua tristeza dois filhos ainda crianças, tenha chegado aqui nu e descalço, solicita muito humildemente que $V .{ }^{\text {as }}$ Ex. ${ }^{\text {as }}$ bondosamente mandem fornecer a roupa e pensão necessárias a si e a seus dois pobres filhos, a fim de poder esperar que, em tempo oportuno, $V{ }^{\text {as }}{ }^{2}{ }^{\text {as }}{ }^{2}$ despachem os requerimentos anteriores, segundo as circunstâncias. ${ }^{(9)}$

Haia, 6 de Agosto de 1654.

Assinado Anthonio Paräupaba

\section{SEGUNDA EXPOSIÇÃO DE ANTHONIO PARÄUPABA, BRASILIANO.}

Entregue dia seis de Abril de 1656 a V. ${ }^{\text {as }}$ Ex. ${ }^{\text {as }}$ Estados Gerais dos Países Baixos Unidos. ${ }^{(10)}$

$V^{\text {as }}$ Ex. ${ }^{\text {as }}$ Antonio Paräupaba, nascido Brasiliano e enviado pelos outros Brasilianos, os súditos leais de $V^{\text {as }}{ }^{2} x^{\text {as }}$ declara com toda humildade e a devida reverência, que se passaram quase 20 meses desde que ele, em nome de seus Principais (a mais miserável nação desse mundo e, não obstante, os Brasilianos mais leais a $V^{\text {as }}{ }^{\text {Ex }}{ }^{\text {as }}$ ) expôs brevemente os motivos da sua vinda. ${ }^{(11)}$ Ele apresentou e mostrou o estado triste, miserável e mais que lamentável em que se encontra essa nação fiel, desde a entrega recente do Brasil ao bárbaro, sanguinário, infiel e perjuro Português, pedindo humildemente assistência e ajuda. Durante este tempo ele se alimentou constantemente de esperança e paciência, esperando uma resolução favorável de $V^{\text {as }} \mathrm{Ex}^{\text {as }}$. Porém até agora, para o pesar de sua alma, ele não encontrou coisa alguma que 0 consolasse.Após um silencio tão comprido e assustador viu-se finalmente obrigado a cair mais uma vez aos pés de $V .{ }^{\text {as }}$ Ex. ${ }^{\text {as }}$ para implorar em nome de seus Principais, esses Brasilianos

\footnotetext{
${ }^{(9)}$ Paraupaba diz que ele levou dois filhos com ele, de quem nós não achamos nenhum rastro adicional. A viúva dele pede ajuda posterior para a família dela mas não está claro se estes filhos estão incluídos. Meuwese relata que ele zarpou do Brasil com três crianças e uma mulher em fevereiro de 1654. (MEUWESE, For the Peace and Well Being of the Country, op.cit., p. 206) ${ }^{(10)}$ O manuscrito original foi conservado no Arquivo dos Estados Gerais. Provavelmente foi escrito por um escrivão, mas a assinatura foi feita por uma mão diferente, a de Paraupaba, assim como a correção da ortografia do nome Antoni na primeira página. (DNA ASG 1.01.04. No 5756)O folheto é uma reprodução literal do manuscrito, à parte uma modificação da ortografia. A entrega do segundo requerimento também é registrada no índice de resoluções da WIC no dia 6 de abril 1656. O pedido foi entregue para a Comissão das Índias Ocidentais. (ASG SR 4846: 6 de abril de 1656: 205.)

${ }^{(11)}$ Parece que, apesar da resolução positiva de agosto de 1654, nada aconteceu. O pedido da viúva indica que ele na verdade recebeu um posto como sugerido pelos Estados Gerais aos Gecommitteerde Raden. É provável que Paraupaba tenha passado esses vinte meses nos Países Baixos e que o segundo requerimento tenha sido incitado pela informação vinda do Brasil que Paraupaba menciona depois, quando ele recorre a uma carta interceptada de Vieira.
} 
miseráveis porém leais, que queiram agora $\mathrm{V} .{ }^{\mathrm{as}} \mathrm{Ex} .{ }^{\text {as }}$, preocupadas com o estado tão oprimido deles, conseguir assistência e ajuda segundo sua disponibilidade, nesta hora, conforme o pedido para a salvação dos Brasilianos. Isto é altamente necessário considerando-se o presente estado do Brasil e o sofrimento destas almas miseráveis, assuntos sobre os quais ele achou necessário expor a V. ${ }^{\text {as }}$ Ex. ${ }^{\text {as }}$ o seguinte e breve relato. Assim pede-se com toda humildade $\mathrm{V} \mathrm{V}^{\text {as }} \mathrm{Ex} .{ }^{\text {as }}$, da parte dessa nação miserável, mas leal, observar em clemência quem realmente são esses em nome dos quais ele está estendido aos Vossos pés e vem requerer ajuda e assistência contra 0 perjuro Português, que rompeu o tratado. ${ }^{(12)}$ Ele se vê obrigado, por várias razões, a recordar os primeiros fundamentos ou princípios da relação entre essa nação e Vosso Estado, a decorrente submissão da primeira e sua perseverança com toda lealdade. Declarando em nome de Deus que isso será feito com nenhum outro objetivo no mundo a não ser o de renovar a memória daqueles nessa presente reunião ilustre de $V^{\text {as }}{ }^{2} x^{\text {as }}$, que ainda se lembram do que se passou, e informar àqueles que o desconhecem, sobre os serviços prestados por essa nação com toda lealdade, para assim despertar nos corações de ambos uma compaixão cristã para com esta nação. O primeiro conhecimento que esta infeliz nação teve de $V .{ }^{\text {as }} \mathrm{Ex} .{ }^{\text {as }}$ foi feito através do Almirante Boudewijn Hendricxsz na Bahia de Traição, onde ele, logo depois de sua chegada, tentou fazer aliança com essa miserável nação Brasiliana com promessas e a confirmação da proteção de $V^{\text {as }}{ }^{\text {Ex }}{ }^{\text {as }}{ }^{\left({ }^{(13)}\right.}$ Ele os encontrou imediata e entusiasticamente dispostos ao serviço de $V^{\text {as }}$ Ex. ${ }^{\text {as }}$ quando isto Ihes foi solicitado. Mas ai deles! Foram logo abandonados pelo mesmo, apesar da

\footnotetext{
${ }^{(12)}$ Paraupaba define a identidade de sua nação como um discurso histórico. Ele nunca recorre a identidades indígenas como Potiguar, Tupinambá ou Tapuia. A referência à Bahia da Traição implica uma identidade Potiguar, como é documentado em Frei Vicente do Salvador, História do Brasil. Parece que Paraupaba evade este ponto. Ele prefere descrever sua nação em relação ao português e ao holandês, adotando um discurso europeu. As referências no primeiro requerimento sobre o extermínio de índios nas Américas aparecem como um tema recorrente em folhetos neerlandeses e outra literatura depois da revolta em 1572. Os neerlandeses se comparam aos índios americanos enquanto vítimas da "tirania espanhola" (SCHMIDT, Innocence Abroad, op.cit.).A linguagem que ele usa é bíblica, bastante diferente dos discursos índios como aqueles registrados por Léry ou Abbeville. Cristina Pompa faz um comentário sobre esta habilidade do Potiguar em adotar discursos diferentes, comparando os de Paraupaba e Poti àqueles de Camarão. POMPA, Religião como Tradução, op.cit., pp. 209-210).

${ }^{(13)}$ A chegada da frota do Almirante Hendricxsz na Bahia da Traição no dia 20 de junho de 1625 é documentada por de Laet. Hendricxsz tinha partido em março de 1625 dos Países Baixos mas chegou tarde demais para ajudar os holandeses em Salvador da Bahia. A baía serviu como um ancoradouro seguro para a frota da WIC que se achava em uma costa a sotavento. De Laet escreveu: "Os Brasilianos que moravam nas terras adjacentes, vieram ter com os nossos, e lhes ofereceram seus serviços contra os Portugueses". Hendricxsz deixou 700 mortos no Brasil, de modo que a parada deve ter sido mesmo muito necessária. (LAET, Historia ou Annaes dos feitos, op.cit., vol. 1, pp. 95-98)
} 
proteção que Ihes foi garantida, depois de prestarem vários serviços contra os Portugueses. ${ }^{(14)}$ Essa nação miserável teve que pagar por isso com o sangue de milhares de homens, mulheres e crianças. $O$ primeiro contato com $V .{ }^{\text {as }}$ Ex. ${ }^{\text {as }}$ foi pago tão caro que esta nação pode dizer com razão que a sua primeira união com este Estado foi assinada e selada, de sua parte, com 0 sangue das suas mais valorosas jóias, através do ódio eterno e intransigente contra aqueles Portugueses sanguinários. Quais torturas, quais tormentas e quais massacres eles sofreram e suportaram desde aquele tempo até a chegada do General Waerdenborgh. Nem a língua pode falar, nem a caneta pode descrever. Só o conhece aquele grande e onisciente Deus que diz: a vingança é Minha. ${ }^{(15)}$ Após a chegada do Senhor Waerdenborgh na Capitania de Pernambuco, os poucos que restavam desses miseráveis retornaram à proteção e à obediência $\mathrm{a} V .{ }^{\text {as }} \mathrm{Ex} .{ }^{\text {as }}$, de acordo com suas próprias possibilidades e em tempo oportuno. ${ }^{(16)} E$ daí em diante constantemente juntaram as suas armas com as de V. ${ }^{\text {as }}$ Ex. ${ }^{\text {as }}$ para a destruição dos Portugueses, também fora do Brasil, até mesmo na África, na conquista de Angola, sob os estandartes de V. as

${ }^{(14)}$ A frota velejou novamente em primeiro de agosto. De Laet escreve: “...por outro lado
abandonar os Brasilianos, que se deram muita pressa em se lançar com ele, e por fazerem
conta que as nossas aqui permaneceriam, já haviam practicado tantas hostilidades contra os
Portugueses, era duro e estranhavel [...] Os Brasilianos, sabendo que os nossos estavam
deliberados a partir, ficaram também mui perplexos, pois previam qual a sorte que os aguar-
dava, por ser certissimo que os portugueses os haviam de castigar e tomar emenda deles.
Muitos trabalharam com os nossos que os levassem, mas, como não havia para isto bastantes
provisões, sómente poucos foram aceitos, e força foi que a mór parte deles se lançasse a
monte". Os serviços dos brasilianos são descritos por de Laet. Eles lutaram com os holan-
deses contra forças portuguesas e os ajudaram a achar comestíveis frescos. (LAET, Historia
ou Annaes dos feitos, op.cit., vol. 1, p. 96).

${ }^{(15)} \mathrm{O}$ tema de um laço mútuo com o holandês em um ódio comum ao português e uma vingança subseqüente é retomado constantemente no discurso de Paraupaba. Isso corresponde à visão da vingança e da guerra como elementos importantes na cultura Tupi. (FERNANDES, Florestan. Organização social dos Tupinambá. 2a ed. São Paulo: Difusão Européia do Livro, 1963, pp. 11-125; MONTEIRO, "The Heathen Castes of Sixteenth-Century Portuguese America", op.cit., pp. 715-716).

${ }^{(16)}$ A chegada de General Waerdenborgh é uma referência à invasão de Pernambuco pelo Almirante Loncq, que conduziu uma frota da WIC em 1630. Diederick Waerdenburgh era o chefe das forças terrestres. Ele escreveu: "Os Brasilianos não são cordeirinhos como os pintam certas histórias das Índias Ocidentais que li; são antes soldados valentes, prontos e audaciosos, como têm mostrado". A população indígena de Pernambuco e Paraíba iniciou relações evidentes com os Neerlandeses, depois da conquista das principais fortalezas portuguesas em 1635. Frei Manoel escreveu: "Tanto que os índios da terra Pitiguares, [...] viram as duas fortalezas do Arraial e Nazaré rendidas [...] e logo começaram a sair com os Holandeses em tropas, ensinando-lhe os caminhos que eles não sabiam, e esquadrinhando os matos, por entre os quais muitos moradores estavam escondidos com suas famílias..”. Os brasilianos se tornaram uma parte integrada das táticas militares holandesas no Brasil. (BOXER, The Dutch in Brazil op.cit., p. 52; MELLO, Tempo dos Flamengos, op.cit., p. 199; CALADO, O Valeroso Lucideno, op.cit., vol. 1, p. 66; MEUWESE, For the Peace and Well Being of the Country, op.cit., p. 159). 
Ex. ${ }^{\text {as }}{ }^{\left({ }^{(17)} F i n a l m e n t e, ~ t e n d o ~ d e s c a n s a d o, ~ c o m o ~ o s ~ o u t r o s ~ s u ́ d i t o s ~ d e ~\right.} V .{ }^{\text {as }} E x{ }^{\text {as }}$, sob aquela sombra enganadora do tratado de Portugal, concluído e jurado no ano 1640 entre $V^{\text {as }}$ Ex. ${ }^{\text {as }}$ e aquele pérfido e autoproclamado Rei, ${ }^{(18)}$ foram eles que, antes de todos, logo depois da rebelião instigada pelos perjuros Portugueses no ano 1645 no Brasil, ${ }^{(19)}$ tiveram de provar a fúria cruel desses desleais na rendição de Serinhaem, onde, contra o acordo concluído, todos dessa nação, até mulheres e crianças, saciaram com seu sangue, pela forca e pela espada, os corações sanguinários desses Portugueses perjuros. ${ }^{(20)}$ Não é a intenção relatar aqui $V_{V}{ }^{\text {as }}$ Ex. ${ }^{\text {as }}$ todos os serviços leais, as desgraças e as misérias sofridas por essa nação nos últimos nove anos. Somente fornecer uma relação breve duma prova de sua lealdade incorruptível na grande fome nos anos 1645 e 1646, quando os súditos de $V_{\text {. }}^{\text {as }}$ Ex. as (excluída essa triste nação) recebiam dos armazéns apenas uma libra de pão por semana para viver.O inimigo oferecia então muitos prêmios para que ela [a nação Brasiliana sic] se aliasse a ele. Além disso, foi declarado claramente pelo Alto Governo que, tendo em vista a grande fome nesta ocasião, ela poderia se servir desta proposta do inimigo, para alimentar a si, suas mulheres e crianças, até que Deus Todo Poderoso providenciasse uma mudança para melhor.Assim pareceu mais honesto e louvável para essa leal nação Brasiliana comer as sementes e a casca das árvores, e até o orvalho do campo, e

${ }^{(17)}$ Duzentos e quarenta índios brasilianos velejaram do Recife no dia 30 de maio de 1641 , como parte de uma força de 3000 sob as ordens do Almirante Jol e do Coronel Henderson para conquistar Luanda no dia 26 de agosto de 1641. Só 48 voltaram às suas aldeias, o que fez os Senhores XIX proibirem outra participação brasiliana na expedição africana de 1642 . (SCHALKWIJK, Igreja e Estado no Brasil Holandês, op.cit., 289).

${ }^{(18)} \mathrm{O}$ tratado entre a República holandesa e o rei português foi assinado, sob certas condições, no dia 18 de novembro de 1641. Johann Moritz conquistou Angola e o Maranhão sob tais condições, o que causou protestos dos portugueses que disseram que estas conquistas foram feitas ao contrário do espírito do tratado. (BOXER, The Dutch in Brazil, op.cit., pp. 104-108). ${ }^{(19)}$ A revolta dos moradores começou em julho de 1645 . O descontentamento era particularmente forte entre os donos dos engenhos em Pernambuco, que estavam falidos, com a WIC sendo seu credor exclusivo. Os historiadores concordam que o Rei português fez pouco para apoiar a revolta inicial. (MELLO, Olinda Restaurada, op.cit.; BOXER, The Dutch in Brazil, op.cit., p. 228; MELLO, O Negócio do Brasil, op.cit., pp. 61-102).

${ }^{(20)}$ A guarnição holandesa de Serinhaem se rendeu aos Portugueses no dia 6 de agosto de 1645. Os aliados brasilianos dos holandeses foram executados pela espada e suas mulheres e crianças divididas como escravos entre os moradores. Calado descreveu a cena, justificando a execução porque eles, como súditos portugueses criados pela Igreja católica, tinham se rebelado.Para uma descrição holandesa destes eventos, ver Nieuhof, que os testemunhou e também publicou documentos do arquivo da WIC, como uma carta onde Vidal rejeita reclamações do Alto Conselho sobre a execução de brasilianos com o argumento de que o mesmo Conselho tinha declarado que o português que se rebelou não receberia nenhuma clemência, autorizando assim os brasilianos a matá-los. (CALADO, O Valeroso Lucideno,op.cit., vol. 2 p. 77; NIEUHOF, Memorável Viagem Marítima e Terrestre ao Brasil, op.cit., pp. 179-180). 
morrer aos milhares, perseverando na lealdade a este Estado, do que sujar a fidelidade, selada a tão altos custos, e ficar com a marca eterna da desonra por desertar para o lado inimigo por causa da fome.Chamando aqui Deus e todos os presentes naquela época em Itamaracá como testemunhas (dessas insuportáveis, inauditas e lamentáveis fomes e misérias contra as quais essas almas leais lutaram tanto tempo) de que nisso se mostra $a \mathrm{~V} .{ }^{\text {as }} \mathrm{Ex} .{ }^{\text {as }}$ nada mais do que a sincera verdade. ${ }^{\left({ }^{21}\right)}$ Queiram $V .{ }^{\text {as }}$ Ex. ${ }^{\text {as }}$ observar que tudo que essa nação miserável encontrou no serviço das $V .{ }^{\text {as }} E x{ }^{\text {as }}$ e que foi agüentado e suportado por ela tão corajosamente, não foi feito por um povo sem conhecimento do Deus verdadeiro, mas por um povo que com a aliança com V. ${ }^{\text {as }}$ Ex. ${ }^{\text {as }}$ também abraçou e adotou a verdadeira Religião Reformada Cristã.Um exemplo vai indicar brevemente como Deus, Pai de todas as graças, já despejou os dons da sua misericórdia sobre essas pobres almas.Pedro Poti ${ }^{(22)}$ regedor dessa infeliz nação, tendo caído prisioneiro dos Portugueses a 19 de Fevereiro 1649, na segunda funesta batalha de Guararapes, ${ }^{(23)}$ tão barbaramente tratado por aqueles algozes (cujas crueldades desumanas excedem em muito a

(21) O Alto Conselho ordenou que Carapeba se retirasse com os brasilianos para a ilha de Itamaracá em julho de 1645. Nas resoluções do Alto Conselho de 27 de agosto de 1645 , consta que ele lá ficou com 1200 brasilianos, dos quais 499 eram guerreiros. Calado atribui a repulsão de um ataque pelo português na aldeia de Schoppe em setembro de 1645 a estes brasilianos. Nieuhof fornece uma descrição elaborada dos eventos em Itamaracá entre 1645 e 1646. O Alto Conselho não podia alimentar os brasilianos e sugeriu que eles fossem para o Rio Grande, o que eles recusavam a fazer, com medo de serem abandonados lá. Listrij os persuadiu e 1200 brasilianos, principalmente mulheres e crianças, foram transportadas para o Rio Grande onde eles chegaram em junho de 1646, tão debilitados pelo fome que quase não podiam caminhar. Não há nenhuma menção de qualquer permissão para fugir para o lado inimigo; pelo contrário, há uma preocupação constante do Alto Conselho de que os brasilianos pudessem desertar (OWIC 70, 71; CALADO, O Valeroso Lucideno, op.cit., vol. 2, pp. 133134; NIEUHOF, Memorável Viagem Marítima e Terrestre ao Brasil, op.cit., pp. 224-251). ${ }^{(22)}$ Pedro Poti era um dos líderes indígenas proeminentes no Brasil holandês. A tradução de Souto Maior realçou a descrição que Paraupaba fez da provação dele. Seu nome é grafado de muitas formas: Poti, Pottij e Poty. Poti fez parte do primeiro grupo de índios que viajou para os Países Baixos em 1625. Ele voltou ao Brasil depois da invasão de 1630 para agir como intérprete e mediador. Ele é registrado como Capitão da Aldeia Masurepe na Paraíba no relato de van der Dussen em 1639. Poti foi repreendido mais de uma vez pelo Alto Conselho por comportamento desordenado em 1642 (Listrij, Comandante dos brasilianos, escreveu que Poti era alcoólatra).Após a assembléia, ele foi designado como Regedor da Paraíba em 1645. Depois de julho, ele operou primeiro a partir do Forte Margarida, e depois em 1646 há registros de que ele tenha lutado ao redor de Igarassu. Ele escreveu uma missiva ao Alto Conselho no dia 13 de dezembro de 1647, da Aldeia Schoonenborch sobre os atrasos nos pagamento para os brasilianos: "pedindo que o Alto e Poderoso queira cobrir a nudez do suplicante". Poti também pediu faixas, chapéus com plumagens para seus oficiais, e presentes para suas esposas. Veja para maiores informações sobre Pedro Poti: MEUWESE, For the Peace and Well Being of the Country, op. cit., pp. 149-216 (OWIC 70, 71, 72). 
imaginação), foi açoitado, sofreu toda espécie de tormentos, e foi atirado em um buraco escuro, tendo as mãos e pés presos juntos por correntes de ferro, recebendo por alimento menos do que um pouco de água e de pão, e lá ficando por seis meses, chafurdando em sua própria sujeira.A concessão que lhe davam algumas vezes para sair dali, uma ou mais horas, para gozar da luz do dia, só servia para dobrar, renovar e até aumentar as suas aflições. Quando logo em seguida se via repentinamente cercado de padres e monges, e de alguns dos seus 'patrícios', instigados pelos primeiros, que continuamente o incitavam a abjurar a religião verdadeira reformada (que eles, como de hábito, chamavam da mais maldita heresia) e a lançar-se de novo no seio da Igreja Romana. ${ }^{(24)}$ Além disso, empregaram todos os meios para que [Poti sic] induzisse os outros da sua nação, que se conservavam fiéis no serviço de $V^{\text {as }}$ Ex. ${ }^{\text {as }}$, a passarem para o partido deles, prometendo dar-lhes imediatamente a patente de capitão e garantindo-lhes maiores vantagens para o futuro.Invoco aqui o testemunho de todas as pessoas que se achavam presas naquele tempo com ele no Cabo de S. Agostinho. ${ }^{(25)}$ Aquele grande Deus de Misericórdia fortaleceu aquela cana frágil, através de sua graça singular, transformando-a em um forte pilar da Fé, pois ele, muitas vezes, durante o período desses seis meses do seu martírio, como narrado acima, sendo rogado a abjurar, respondeu sempre com ânimo incorruptível.Que ele, um indigno, tendo,

\footnotetext{
${ }^{(23)}$ Esta batalha foi uma derrota decisiva para as forças da WIC. Poti e Paraupaba devem ter ficado enfurecidos com o desempenho pobre da milícia da WIC, parte da qual tinha ameaçado entrar em greve alguns dias antes da batalha por não terem recebido seus salários. Os brasilianos pediram a indicação de um novo Regedor para substituir Poti no dia 22 de fevereiro de 1649. Carapeba registrou um requerimento sobre a captura de Poti cinco dias depois. O Alto Conselho repreendeu Paraupaba por se comportar mal, depois de reclamações do predicante Kemp no dia 15 de março de 1649. A desculpa dele é datada de 19 de março e chegou ao Alto Conselho no dia 16 de abril. O Alto Conselho enviou uma missiva ao inimigo no dia 19 de abril de 1649, contestando o tratamento de Poti. Eles receberam uma resposta rápida depois de três dias. A resposta de Francisco Barreto, chefe das forças portuguesas, declarava que Poti estava sendo mantido preso pelos seus parentes e que eles deveriam o estar tratando do modo merecido. Poti viveu durante dois anos e meio preso em correntes e morreu na viagem para Portugal. (OWIC 73; SCHALKWIJK, Igreja e Estado no Brasil Holandês, op.cit., p. 309; MEUWESE, For the Peace and Well Being of the Country, op.cit., p. 201).
}

${ }^{(24)}$ A referência aos patrícios de Poti sugere que a nação Potiguar estava profundamente dividida e que Pedro Poti era considerado um símbolo importante. Poti quer dizer camarão em tupi. Pedro era parte do clã de elite Potiguar. Na segunda carta "índia” no arquivo da WIC há referência ao avô Aroerena e ao pai Iaguarani. Na terceira carta Diogo da Costa escreveu: " $o$ vosso irmão Lippe Tocaju morreu e nossa mãe morreu" (SOUTO MAIOR, "Fastos Pernambucanos", op.cit., pp. 150-151).

${ }^{(25)}$ Hondius tinha sido prisioneiro no Cabo S. Agostinho onde ele morou muito tempo e foi vereador. Muitos prisioneiros ficavam no Cabo antes de ser transportados para Salvador. O reverendo Stetten poderia ter visto Poti porque ele foi capturado antes de Poti e ainda poderia estar na prisão por volta de agosto de 1649 (SCHALKWIJK, Igreja e Estado no Brasil Holandês,op.cit., p. 309) 
por uma mercê não merecida e incompreensível, reconhecido a Deus e ao Pai de todas as graças na verdadeira religião, a Reformada, que tinha a certeza de ser não só a verdadeira, mas a única aprazível a Deus, e que estava resolvido a não abandoná-la nem na vida e nem na morte.Que achava pouco todos os tormentos de que usaram consigo e os que ainda iriam empregar, pois estava preparado pela graça de Deus para os enfrentar, agradecendo ao Grande Deus por tê-lo considerado, por sua especial graça, a ele, a mais indigna de todas as criaturas, merecedor de sofrer, em nome de Jesus Cristo seu Salvador.Finalmente, que estava pronto a morrer firme no seu alto juramento feito a Deus e aos Estados Gerais. Resultou disso, decorridos os ditos seis meses, que aqueles sanguinários, vendo que de um ânimo tão forte nada se poderia conseguir, nem por meio de martírios, nem por promessas de honrarias, cargos ou fortuna, tiraramno do buraco escuro onde tanto sofreu, sob o pretexto de o quererem mandar a Bahia, quando seu plano era matá-lo cruelmente, o que depois se realizou. Estando ele pronto para o matadouro, ainda disse aos diversos oficiais de $V .{ }^{\text {as }}$ Ex. ${ }^{\text {as }}$ presos com ele no Cabo S. Agostinho."'Sei que eles me matarão. Peço-vos, portanto, que me presteis o seguinte serviço: Quando regressardes ao Recife, contai aos do Alto Governo o que vistes e ouvistes de mim; que eu morri como seu súdito fiel. E dizei aos da minha nação que os exorto a permanecer por toda a vida fiéis a Deus e aos Estados Gerais". ${ }^{(26)} O$ suplicante, além disso, pede a V. ${ }^{\text {as }}$ Ex. ${ }^{\text {as }}$, em nome desses homens miseráveis, para que entendam com coração e alma os princípios da graça maravilhosa de Deus nesse pobre povo. Como gostou o Onipotente de já levar muitas dessas criaturas pobres da escuridão para a luz e do poder de Satã para Ele mesmo. Como agradou a sua Majestade Divina chamar e usar as $V .{ }^{\text {as }} \mathrm{Ex}^{\text {as }}$ (que também foram redimidos do paganismo) para pregar a eles o seu Santo Evangelho. ${ }^{(27)}$ Este instrumento é na realidade a libra ou o talento que foi tão fortemente recomendado $\mathrm{a} V$. ${ }^{\text {as }}$ Ex. ${ }^{\text {as }}$ para colocar em usura. Queiram gastar o mesmo para 0 lucro desses miseráveis, assim que quando o Patrão Severo voltar um dia para acertar as contas,

\footnotetext{
(26) Paraupaba descreveu Poti como um mártir, não dos Potiguar ou da nação indígena, mas da religião reformada. Poti colocou a visão dele de cristianismo decisivamente em sua carta a Camarão: "Sou cristão e melhor do que vós, creio só em Cristo [...] aprendi a religião cristã e a pratico diariamente". Clérigos holandeses, por outro lado, estavam desesperados com a possibilidade de resgatar os índios, "dados os seus vícios inveterados, prostituição, alcoolismo e preguiça”. O próprio Poti foi repreendido mais de uma vez. Poti morreu como um mártir e deve ter achado consolação em sua fé durante a provação.Paraupaba cita Poti dizendo “que eu morri como seu súdito... fiel a Deus e aos Estados Gerais”, comprovando a lealdade exigida na carta patente de 1644 e até o reconhecimento do papel do Alto Governo em Recife como autoridade. (MELLO, Tempo dos Flamengos, op.cit., p. 223; MEUWESE, For the Peace and Well Being of the Country, op.cit., pp. 177-178)

${ }^{(27)}$ Isto parece ser um breve relance de retórica indígena que se assemelha aos exemplos no comentário sobre Cambressive. Paraupaba se dirige a reunião de políticos neerlandeses como parceiros, convertidos do "paganismo" igual aos indígenas que ele representa.
} 
ele observará como $V^{\text {as }}{ }^{2} x^{\text {as }}$ foram fiéis em seu serviço fazendo crescer o seu Santo Evangelho. ${ }^{(28)} O$ perigo para o corpo e para a alma, $\mathrm{V}^{\text {as }} \mathrm{Ex} .{ }^{\text {as }}$, em que se encontram essas pessoas miseráveis com a triste rendição do Brasil e o abandono desses desgraçados às garras dos sanguinários Portugueses, seus inimigos mortais, está grande demais. Eles já teriam sido exterminados, se não tivessem sido salvos de forma misteriosa e por meios inesperados por esse Deus benevolente e misericordioso. Asalvação veio da [sic] discórdia e da rebelião dos Brasilianos, Negros e Mulatos que formavam a força e o poder das armas dos Portugueses. Eles, tendo se levantado contra seus mestres ingratos, apoderaram-se de uma parte grande do campo, como está claramente apresentado nas cartas interceptadas de João Viero e outros, cujas cópias estão anexadas. ${ }^{(29)}$ De modo que agora apareceram o momento e a oportunidade para $V .{ }^{\text {as }}$ Ex. ${ }^{\text {as }}$ se apoderarem de um dos reinados mais belos e valiosos do mundo com uma força pequena, e ao mesmo tempo para salvarem essa nação tão miserável, mas tão leal, da sua ruína total. A luz da Palavra Santa de Deus, que de outro modo por falta de professores está para ser apagada para sempre, poderá ser acesa de novo no seu meio.V. ${ }^{\text {as }}$ Ex. ${ }^{\text {as }}$, é agora ou nunca mais que se poderá recuperar 0 que $V^{\text {as }}$ armas ganharam tão honradamente nesta guerra contra tal grande e poderoso Rei da Espanha, e que um Rei de Portugal, que se autoproclamou (e cuja coroa cambaleante foi firmada em sua cabeça perjura por $V^{\text {as }}{ }^{\text {Ex }}{ }^{\text {as }}$ ) furtou tão traiçoeiramente sob a aparência de paz. ${ }^{(30)} E$ É

${ }^{(28)}$ Paraupaba repete a referência à parábola do primeiro requerimento no sentido de um aviso que implica que as $\mathrm{V} .{ }^{\text {as }}$ Ex. ${ }^{\text {as }}$ podem também terminar num buraco, como Poti, se não gastarem seu talento. Mateus 25:30: E lancem fora o servo inútil, nas trevas, onde haverá choro e ranger de dentes.

${ }^{(29)}$ A referência à revolta significa que Paraupaba teve informação do Brasil. A carta anexada sugere uma relação com um tradutor, porque a carta seria propriedade da WIC ou do Almirantado. Outro canal de informação poderia ter sido provido através de indígenas viajando entre o Brasil e os Países Baixos como Carapeba, o terceiro Regedor que pede e recebe alimento em julho de 1656. A ortografia errada do nome de João Fernandes Vieira é curiosa e indica que o tradutor não era familiar com a situação no Brasil, ou é um erro de cópia. Hondius publicou a carta junto com os requerimentos de Paraupaba como uma "Tradução do português de uma carta escrita da Paraíba, datada de 22 de setembro de 1655, por Juan Fernando Viero, para Marcos Rodrigues Stinoque em Lisboa". A participação volumosa da população africano-brasileira na insurreição de 1645 contra o governo de WIC não foi analisada de um ponto de vista holandês. O holandês vinha criticando práticas coloniais ibéricas na América desde a revolta na década de 1570 . Eles também tinham se apresentado como libertadores nas Américas. Antes de 1645, eles tinham aparentemente se tornado impopulares com uma parte grande da população africana.

${ }^{(30)}$ Paraupaba compara o rei de Portugal recém coroado e ainda inseguro com o "grande e poderoso rei de Espanha”. Este é o discurso político correto naquele tempo, uma vez que o espanhol tinha se tornado aliado dos holandeses em 1648. O "firmamento de uma coroa cambaleante", a ajuda da República na restauração do trono português, é descrito por BOXER, The Dutch in Brazil, op.cit., p. 108. 
chegada a hora para a vingança justa de $V .{ }^{\text {as }}$ Ex. ${ }^{\text {as }}$ sobre aquele lusitano perjuro, que foi 0 primeiro a pisar sobre 0 armistício e a zombar da brandura de $V^{\text {as }}$ Ex. ${ }^{\text {as }}$.É chegada a hora em que $V{ }^{\text {as }}{ } E x{ }^{\text {as }}$ podem se vingar dessa nação esquecida por Deus, que não exitou em importunar os ossos dos súditos de $V .{ }^{\text {as }}$ Ex. ${ }^{\text {as }}$ nos seus lugares de descanso, que os desenterrou nas igrejas e nos cemitérios com esse fim, e jogou no mar os ossos das crianças na presença dos pais, os dos pais na presença das crianças, os das esposas na presença dos maridos e dos maridos na presença das esposas, colocando-os em latrinas para maior ofensa e ferimento do coração. ${ }^{(31)}$ Esta presente oportunidade foi entregue nas mãos de $V^{\text {as }}{ }^{2} x^{\text {as }}$ por este grande Deus. Se a deixarem passar, vão causar um furto de bens sem fim dos pobres e angustiados súditos de $V^{\text {as }}$ Ex. as . Sim, vão causar a perdição inteira e extermínio total dessa nação miserável dos Brasilianos, que foi tão valiosa para $V^{\text {as }}{ }^{2} \mathrm{Ex}^{\text {as }}$ e este Estado, e que os sanguinários Portugueses tentaram de tempos em tempos e de todas as formas extinguir por completo, vendo que a sua tirania aí não poderia ser estabelecida sem o extermínio dessa nação. ${ }^{(32)} \mathrm{V} .{ }^{\text {as }} \mathrm{Ex}$. , é seguro e certo que este traidor sem vergonha, se encontrando tão oprimido e com medo que $V .{ }^{\text {as }}$ armas justas ataquem-no na inconveniência de seus negócios, vai se apresentar um desses dias, através de suas criaturas, nesse país com propostas para novas negociações, e vai prometer montanhas de ouro, segundo suas burlas habituais. Porque a sua intenção é nada mais que dar um punhado de chumbo, com

${ }^{(31)} \mathrm{O}$ tema da vingança pela profanação dos ossos dos mortos parece uma representação de cultura indígena no requerimento. Em muitas culturas indígenas, os ossos dos antepassados indicam a relação e, portanto, identidade dos vivos com o passado. Barlaeus descreve o valor que os índios atribuem à integridade do corpo do defunto e a duração longa dos seus ritos funerários. Darcy Ribeiro descreve um funeral no romance Maíra. Os ossos dos antepassados são guardados cuidadosamente, às vezes decorados. A destruição intencional destes ossos, pelo seu lançamento ao mar, junto com excrementos humanos, poderia ser interpretado como uma tentativa maliciosa de destruir a identidade da nação viva. As minutas diárias do Alto Conselho de 31 de janeiro de 1654 mencionam que os jesuítas exigiram que os holandeses fossem obrigados a levar seus mortos do Recife e de fato desenterravam dos cemitérios e lançavam no mar os ossos de não-católicos que eles achavam. Há uma referência a este assunto em um folheto publicado em Middelburg. (FERNANDES, Organização dos social Tupinambá, op.cit., pp. 166-201; SCHADEN, Egon, Aspectos Fundamentais da Cultura Guarani, pp. 134-138; OWIC 75; Cort, Bondigh ende Waerachtigh de Verhael, item 82)

${ }^{(32)}$ Paraupaba, na verdade, usa aqui o argumento de genocídio. 
cujo prejuízo V. ${ }^{\text {as }}$ Ex. ${ }^{\text {as }}$, pela sua própria experiência, já arcaram o suficiente. ${ }^{(33)} \mathrm{O}$ suplicante mostrou brevemente, pelas razões citadas acima, com toda humildade perante $V^{\text {as }}{ }^{\mathrm{Ex}} .{ }^{\text {as }}$, os citados serviços leais prestados por essa nação Brasiliana a esse Estado, as muitas e inauditas misérias sofridas, os massacres feitos pelos Portugueses desde o primeiro conhecimento e união dela com V. ${ }^{\text {as }}$ Ex. ${ }^{\text {as }}$. Também foram indicados os princípios fortes da graça de Deus para essas criaturas miseráveis, e como deve-se temer que, pela falta de professores da Palavra Santa de Deus, eles, com o decorrer do tempo, caiam de novo da luz para a escuridão. Também se mostrou a situação oprimida dos negócios portugueses no Brasil, por causa da defecção dos Negros e Mulatos, e a oportunidade nascida para $\mathrm{V}^{\text {as }} \mathrm{Ex} .{ }^{\text {as }}$ de recuperar tudo que o Português perjuro Ihes tomou. ${ }^{(34)}$ Assim, vem se prostrar mais uma vez o suplicante, em nome dessa nação miserável, mas leal, aos pés das $V^{\text {as }}{ }^{2} x^{\text {as }}$, rezando humildemente e pelo querer de Deus, que $V^{\text {as }}{ }^{\text {a }} x^{\text {as }}$ queiram com clemência, em vista de todos os serviços leais e as misérias sofridas por essa nação miserável, e principalmente pelo laço entre $V^{\text {as }}{ }^{E x} .{ }^{\text {as }}$ e ela formado pela religião verdadeira, assisti-la na sua necessidade extrema com dois navios com armas e munição de guerra ${ }^{(35)} \mathrm{e}$, além disso, ajudá-la tão leal e prontamente como ${ }^{\text {as }}{ }^{\text {Ex }}$. ${ }^{\text {as }}$ têm recebido (no seu pedido) pronta

${ }^{(33)}$ Paraupaba refere-se à discussão que se instalou após o rei português rejeitar uma proposta de paz negociada em 1649. Boxer discorda de Paraupaba e postula que foram a ganância e a divisão entre os holandeses que atrasaram as negociações em 1647-1648 e que a segunda derrota de Guararapes tornou politicamente inviável para o rei João IV aceitar o tratado proposto em 1649. A referência à diplomacia portuguesa na República é outra indicação da consciência de Antônio Paraupaba da importância da política européia para a América e a discussão pública nos Países Baixos. (BOXER, The Dutch in Brazil, op.cit., pp. 197, 228-237; MELLO, O Negócio do Brasil, op.cit., pp. 61-202).

${ }^{(34)}$ Paraupaba recapitula seus argumentos: o serviço leal como súdito e o laço da religião reformada justificam a reivindicação de ajuda que ele apresenta aos Estados Gerais. Além disso, surge uma situação especial agora em função do tumulto causado pela revolta dos negros e índios.

${ }^{(35)} \mathrm{O}$ pedido de navios de guerra em relação à discórdia no Brasil foi tema de uma proposta aos Estados Gerais para a conquista de um porto na costa do Brasil. Feito em agosto de 1655 por desconhecidos, menciona nomes de militares desempregados da WIC. O documento inclui uma referência a Henrique Dias que discordou de Francisco Barreto e que tinha juntado 4000 negros e 2000 brasilianos, sobre os quais Antônio Mendes "era que mais comandou". (MELLO, José Antônio Gonsalves de, org. A Rendição dos Holandeses no Recife, 1654. Recife: IPHAN/MEC, 1979, p. 86). Estariam dispostos a se juntar com os holandeses. Repeliram ataques dos portugueses e iriam esperar dois anos no sertão, até os holandeses voltarem. Os planos para a expedição incluíam um navio com presentes como pano, armas e comida para os brasilianos "e outras nações". (MEUWESE, For the Peace and Well Being, op.cit., p. 210: DNA ASG SK 12582-8). 
assistência e ajuda dessa nação, que escolheu provar sua lealdade para com $\mathrm{V}^{\text {as }}{ }^{\mathrm{Ex}}{ }^{\text {as }}$ até a morte, vivendo no bravio e selvagem deserto, na companhia das bestas ferozes e brutas, onde esperam assistência e ajuda somente de Deus e ${\mathrm{de} \mathrm{V}{ }^{\mathrm{as}} \mathrm{Ex}}^{\mathrm{as}}$.O suplicante e sua miserável nação rezarão sem cessar para o Deus de todas as graças e misericórdias, que sua Majestade Divina queira abençoar e fazer prosperar de tempo em tempo, e mais e mais o governo das $V{ }^{\text {as }} E x{ }^{\text {as }}$, e que o Onipotente reconheça às $V .{ }^{\text {as }} E x{ }^{\text {as }} e$ aos seus súditos os benefícios que $V .{ }^{\text {as }} E x{ }^{\text {as }}$ possam vir a conferir a essas pessoas pobres e abandonadas. ${ }^{(36)}$

Assinado:

Anthonio Paräupaba

6 de Abril 1656, Haia

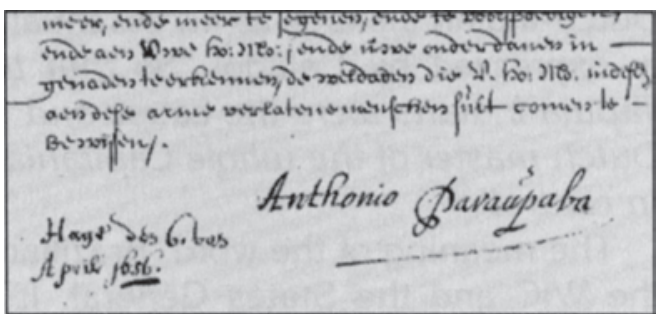

(36) Depois da deliberação pelos Estados Gerais na reunião do dia 6 de abril de 1656, o segundo requerimento foi enviado à comissão das Índias Ocidentais. A viúva Paulina pediu ajuda no dia 12 de julho de 1656, o que significa que Paraupaba deve ter morrido logo após entregar o segundo requerimento (ASG SR 4846). 


\section{Conclusão}

O impacto do contato com os holandeses sobre os povos indígenas no norte e no nordeste do Brasil não deve ser subestimado. O protesto de Paraupaba é a culminação de um processo no qual os brasilianos se provaram peritos em lidar rapidamente com a burocracia holandesa, como mostram as muitas cartas de Poti e de Paraupaba. Parece lógico que os ameríndios lograssem colher informações sobre europeus da mesma maneira que os europeus estudaram os americanos. Os Potiguar adquiriam tecnologia militar européia desde o século XVI e o envolvimento em políticas européias poderia ser visto como uma extensão de suas estratégias ${ }^{26}$.

As "guerras bárbaras" entre 1650 e 1750, nas quais o domínio português foi imposto aos povos indígenas do norte e nordeste do Brasil, mostram que este domínio não havia sido efetivamente estabelecido antes do período do Brasil Holandês. O controle da WIC sobre a Paraíba, Rio Grande e partes do Ceará entre 1645 e 1649 foi largamente apoiado pelas atividades de Poti, Carapeba e Paraupaba, como também pela contribuição dos Tapuias de Janduí, ou de Jan de Wey, em sua grafia holandesa. Esta área corresponde à área descrita por Knivet, no princípio do século XVII, como sendo o domínio dos Potiguar. O Brasil Holandês de Paraupaba, afinal, foi produto da aliança entre brasilianos e holandeses ${ }^{27}$.

\footnotetext{
${ }^{26}$ Frei Vicente do Salvador descreve como os Portugueses destruíram três ferrarias construídas pelos Franceses perto da Bahia da Traição em 1582. (História do Brasil, op.cit., p. 282) Veja, para visitas anteriores de ameríndios aos Países Baixos, MEUWESE, For the Peace and Well Being, op.cit., pp. 72-78. CARVALHO JR., Almir Diniz de. Índios Cristãos: a conversão dos gentios na Amazônia Portuguesa (1653-1769). Tese de Doutorado em História, IFCHUnicamp, 2005, relata a viagem do índio Jorge Tagaibuna para Portugal. A detenção de Paraupaba pelos Tapuia de Janduí em 1634 pode muito bem ter sido provocada pela curiosidade sobre o conhecimento dele da Europa. (LAET, Historia ou Annaes dos feitos, op.cit., Vol. 2, p. 462). Poti escreve na carta dele a Camarão: "Não me faleis sobre a fraqueza dos Holandeses. Estive e me educei no seu país. Existem lá navios, gente, dinheiro e tudo em tanta abundância como as estrelas no céu". É algo que interessaria um senhor de guerra que procura aliados. Há muitas indicações de que os neerlandeses permaneceram ativos no Brasil depois de 1654, especialmente na costa do norte, e novas pesquisas poderão descobrir valiosas informações sobre este período.
}

${ }^{27}$ HEMMING, Red Gold, op.cit., pp. 160-182. 
O discurso de Paraupaba é um reflexo desta aliança. Sua linguagem bíblica, a ênfase no calvinismo e suas obrigações morais, não apenas chama a atenção como um exemplo dos efeitos da missão protestante holandesa mas também mostra uma certa "malícia" indígena que fez os clérigos reformados e católicos se desesperarem. Paraupaba cita a "libra na terra que tem que ser posta em usura" da Bíblia para apoiar seu pedido de ajuda, recorrendo à noção de "intendência", a qual ele sublinha em seu segundo protesto com a observação de que os Senhores Altos e Poderosos dos Estados Gerais foram resgatados do paganismo do mesmo modo que ele foi.

Por outro lado, as referências a Paraupaba feitas pelo clero holandês são na realidade negativas, como foi mencionado na introdução. O relato dele deve ser visto sobretudo como um documento diplomático. Os dois textos de Paraupaba foram escritos com um objetivo político: reivindicavam uma presença militar holandesa no Brasil. Os holandeses percebiam seus aliados índios também principalmente como militares, como é mostrado pelos casos de Carapeba e Paraupaba, que foram recompensados com postos militares. Esta visão da aliança holandês-indígena como uma condição essencialmente militar é expressa até mais fortemente por Calado: "Assim que os malvados e ingratos índios Pitiguares, e Tapuias foram a causa, e o principal instrumento de os Holandeses se apoderarem de toda a Capitania de Pernambuco, e de a conservarem tanto tempo"28.

A questão da escravidão constitui outro aspecto importante das relações neerlandês-indígenas no Brasil, o que pode contribuir para um entendimento melhor da dinâmica socio-econômica que conduziu ao envolvimento holandês no tráfico de escravos no Atlântico. A primeira reivindicação da embaixada brasiliana de 1644 para os Senhores XIX era a libertação dos escravos. O pedido de ter "vereadores" sugere que as câmaras de "escabinos", ou vereadores, instituídas pela WIC desde 1636 nas freguesias do Brasil Holandês, protegiam os interesses dos moradores "escravistas". Os neerlandeses no Brasil não se mostraram muito diferentes do que os portugueses no tocante à escravidão, apesar do discurso oficial. A própria WIC vendeu escravos indígenas e Gideon Morris atribuiu a revolta dos índios no Ceará ao tratamento dispensado pelos neerlan-

${ }^{28}$ CALADO, O Valeroso Lucideno, op.cit., Vol. 1, pp. 66-67. 
deses $^{29}$. Morris escreveu do Maranhão em 1642: “os que são livres só tem nome de livres e de fato são escravos, pois é bastante servo quem está obrigado a trabalhar um mês por três varas de pano que tal é aqui o seu salário ordinário". Barleaus complementou: "Deu, sem dúvida, o Conde [Nassau] notável e raro exemplo de justiça e de eqüidade para com os bárbaros, cumulando-os com todo o gênero de benefícios e decretando para os seus trabalhos digna paga e para os seus serviços e misteres justa remuneração.[...] Regulou-lhes de tal modo os jornais e soldos que nem despertasse a superfluidade, nem lhes permitisse outra pobreza senão uma pobreza honesta". Se Nassau e o Alto Conselho apoiaram a política de libertação dos indígenas no discurso, parece que na realidade não conseguiram implementá- $\mathrm{la}^{30}$.

Paraupaba não se refere a Nassau nos seus textos, nem à Companhia das Índias Ocidentais. Ele se refere a Boudewijn Hendricxsz e Waerdenburgh como representantes dos Estados Gerais. Ele se coloca como um guerreiro aliado. Esta lealdade lhe rendeu um posto de algum prestígio. O soldo dele em 's Hertogenbosch de "twee ruijters paijen" somava 50,- florins por mês, igual ao de um Major ou Capitão no exército dos Estados Gerais ${ }^{31}$.

Meuwese considera Paraupaba um líder pan-índio, sendo este pan-indianismo dele o resultado das mudanças rápidas ensejadas pelas guerras no Nordeste do Brasil. John Monteiro aponta como os indígenas procuravam forjar novas identidades e o exemplo de Paraupaba parece ser um destes casos. Brasiliano seguramente representa uma categoria que surgiu como parte de uma etnogênese resultando do encontro dos ameríndios com os europeus. No contexto do Brasil Holandês, tratava-se de uma identidade de curto prazo, porque os próprios neerlandeses reivindicavam esta identidade para si, no caso dos holandeses que chegaram refugiados do Brasil e que passaram a constituir os brasilianos que encontramos nos arquivos depois de 1654. A publicação do

\footnotetext{
${ }^{29}$ MELLO, Tempo dos Flamengos, op.cit., pp. 206-207. Veja também o estudo de BOOGAART, E. van den, e BRIENEN, Rebecca Parker. "Information from Ceará from Georg Marcgraf (JuneAugust 1639)". In Dutch Brazil. Org. C. Ferrão e J. P. M. Soares. Rio de Janeiro: Index, 2004, pp. 34-35, onde se encontra o relato de uma expedição para capturar escravos no Ceará.

${ }^{30}$ BARLAEUS, História dos Feitos, op.cit., p. 51. MELLO, Tempo dos Flamengos, op.cit., p. 207. ${ }^{31}$ MEUWESE, For the Peace and Well Being, op.cit., nota 239 na p. 209: citando ASG SK 12582.8 .
} 
folheto de Paraupaba em 1657 por Hondius fez parte da reivindicação política destes primeiros "brasilianos holandeses" e é uma das últimas expressões de uma relação entre o Países Baixos e os índios do Brasil como vítimas oprimidas ${ }^{32}$.

O governo português negociou um tratado com os Estados Gerais em 1661, o que incluiu compensação pelas perdas no Brasil. A partir de então, os editores holandeses se concentraram em publicar trabalhos nos quais os ameríndios foram descritos como seres completamente exóticos. As tapeçarias com imagens de Tapuias se tornaram uma moda em círculos aristocráticos franceses. Ao que parece, após de Laet e Hugo de Groot, que debateram a origem dos "Americanos" entre 1642 e 1644, diminuiu o interesse em se ter contato com índios de "carne-e-osso" 33 .

De fato, os neerlandeses já esqueceram em grande parte a relação deles com os índios do Brasil. O ameríndio que segura um escravo, em frente à virgem de Amsterdã e embaixo de Atlas no tímpano ocidental da antiga prefeitura da cidade, passa despercebido pelas pessoas que passam abaixo. Os holandeses parecem também nunca ter tentado uma relação semelhante com outros povos ameríndios, entretanto o discurso holandês de apoio moral para índios oprimidos continua até hoje. O nome dos Potiguar também foi esquecido nos Países Baixos, compreensivelmente, já que nem Paraupaba nem Poti mencionam-no em seus dois manuscritos publicados.

O serviço leal de Dom Antonio Felipe Camarão o transformou em um dos poucos heróis índios na história brasileira. A sobrevivência do Potiguar como uma identidade indígena dentro do Brasil moderno ocorre provavelmente em parte devido à aliança de Camarão. Ele se tornou o símbolo do componente índio na cooperação das três raças na libertação de Brasil do holandês. Entretanto, a libertação da população indígena e dos escravos africanos tinha figurado no discurso dos holandeses. A história de Paraupaba mostra que muitas pessoas

\footnotetext{
${ }^{32}$ MEUWESE, For the Peace and Well Being, cit., pp. 465-466; MONTEIRO, Tupis, Tapuias e Historiadores, op.cit., 55-60. O apelido de "Brasileiro" para Maurício de Nassau confunde a tradução de "Brasiliano" porque este apelido é derivado do apelido dos indígenas, porém sempre é traduzido como Maurício o Brasileiro.

${ }^{33}$ Veja para as negociações com Portugal: MELLO, O Negócio do Brasil, op.cit., pp. 228234, 274-276. LAET, Notae ad dissertationem secundam Hugonis Grotii, recorre extensivamente ao Potiguar ou 'Petivares' na anotação dele da dissertação de Hugo de Groot sobre a origem dos americanos.
} 
nos Países Baixos e no Brasil buscaram seriamente se afirmar, mas não tiveram pleno êxito ${ }^{34}$.

\section{Epílogo}

Carapeba sobreviveu a esse período, diferentemente dos outros dois regedores originais: junto com Paulina Paraupaba, ele reivindicou ajuda dos Estados Gerais no dia 7 de julho de 1656. Paulina repetiu o pedido dela no dia 12 de outubro de 1656, e finalmente no dia 16 de janeiro de 1657 com o pedido de pagamento de dois meses para deixar os Países Baixos. Onze dias antes, Carapeba tinha pedido autorização, que foi concedida, para velejar para Tobago ${ }^{35}$.

\footnotetext{
${ }^{34}$ Para os Potiguares da Bahia de Traição hoje veja: PALITOT, Estêvão Martins. Os Potiguara da Baía da Traição e Monte-Mór: História, Etnicidade e Cultura Dissertação de Mestrado, UFPB, João Pessoa, 2005.

${ }^{35}$ MEUWESE, For the Peace and Well Being, op.cit., pp. 221-223: citando ASG SR 4846.
} 